\title{
The Variscan Deformation Front (VDF) in Northwest Germany and Its Relation to a Network of Geological Features Including the Ore-Rich Harz Mountains and the European Alpine Belt
}

\author{
Heinz-Jürgen Brink \\ Institute of Geophysics, University Hamburg, Hamburg, Germany \\ Email: heinz-juergen.brink@uni-hamburg.de
}

How to cite this paper: Brink, H.-J. (2021) The Variscan Deformation Front (VDF) in Northwest Germany and Its Relation to a Network of Geological Features Including the Ore-Rich Harz Mountains and the European Alpine Belt. International Journal of Geosciences, 12, 447-486. https://doi.org/10.4236/ijg.2021.125025

Received: March 16, 2021

Accepted: May 17, 2021

Published: May 20, 2021

Copyright $\odot 2021$ by author(s) and Scientific Research Publishing Inc. This work is licensed under the Creative Commons Attribution International License (CC BY 4.0).

http://creativecommons.org/licenses/by/4.0/

\begin{abstract}
The crustal basement of Northwest Germany can be interpreted as an "Avalonian Terrane Assemblage" subdivided by a roughly NW-SE (Hercynian) and SW-NE (Rhenish) running horst and graben system. In Late Devonian and Early Carboniferous times, this assemblage was flooded by the sea and mainly marine carbonates were deposited on the horsts and Stillwater shales in the grabens, as interpretable through magnetotelluric measurements. During the Late Carboniferous Variscan Orogeny, this terrain became the coal-rich foreland of the colliding Rhenohercynian belt. The shale-filled grabens reacted through folding and thrusting with different anticlinal patterns, the main carbonate covered horst in a still unknown way. This horst was the location of the Late Carboniferous basin center and of the inverted oil-rich Mesozoic Lower Saxony Basin (southwestern sector), respectively, with the so-called Bramsche Massif therein. It probably acted as an indenter for the evolution of the Variscan ore-rich Harz Mountains and forced the approaching Rhenohercynian orogen to stack the appropriate tectonic nappes by horizontal shortening to very high altitudes and the root into large depths. Based on seismic evidence this root is still an uncompleted crust/mantle transition zone with a deep reflection seismic and petrological Moho and a shallower hardly reflecting refraction seismic velocity Moho. The alternative, partly unsolved location of the Variscan Deformation Front in Northwest Germany may represent the new findings. The results may be supported by a comparison with features of the northern Alpine deformation belt.
\end{abstract}




\section{Keywords}

Variscan Deformation Front, Eastern Avalonia, Harz Mountains, Lower Saxony Basin, Bramsche Massif, Lower Carboniferous, Alpine Deformation

Belt, Moho Seismic Reflections/Refractions, Magnetotellurics

\section{Introduction}

Plate tectonics relates the subsurface of the Central European Basin System, which encompasses, among others, the Variscan Foreland Basin, the North German Basin as central part of the Southern Permian Basin, the inverted Lower Saxony Basin and the North Sea Basin as significant members therein (Figure 1) with the ancient pre-Devonian continent figuration of Africa (Gondwana), Baltica, Avalonia and North America (Laurentia) in a very complex manner [1] (Figure 2). Collisions between those plates resulted in Caledonian orogeny with the development of mountain ranges at its present-day northeastern and northwestern edges. Erosional processes until Early Devonian times helped to flatten portions of the mountain ranges in a way that due to a high sea level at least the eastern part of the microcontinent of Avalonia could be flooded by ocean waters, yielding to the sedimentation of marine carbonates and shales until Early Carboniferous [2] [3] [4]. With closing of the Rhenohercynian Ocean to the southeast Eastern Avalonia [5] [6] [7] with its cover of shallow marine sediments became the resisting unit for the approaching Rhenohercynian belt of the Variscan Orogen.

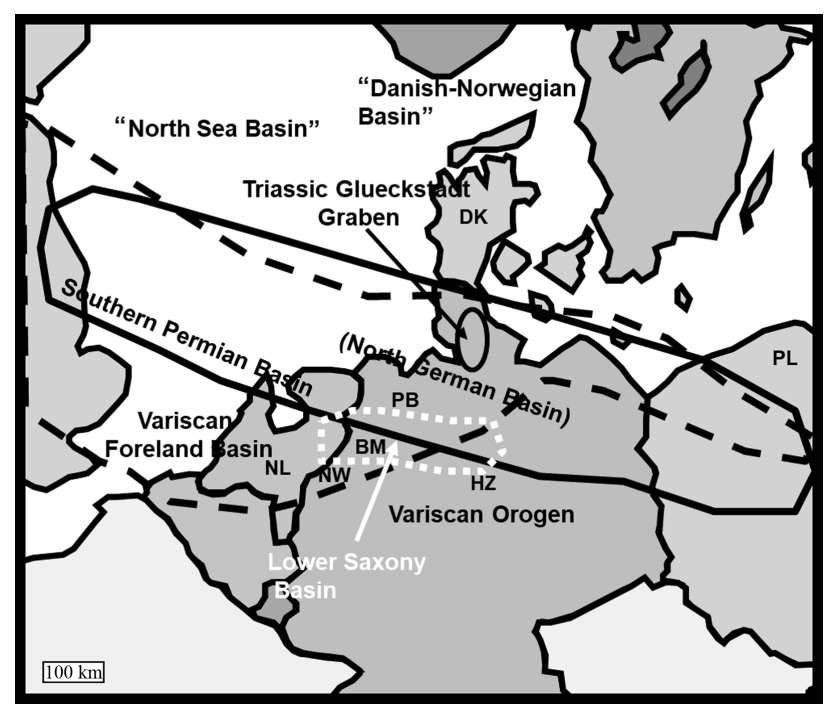

Figure 1. The Central European Basin System (sketched) with the Variscan Foreland Basin (dashed lines), the Southern Permian Basin (continuous line), the Lower Saxony Basin (dotted line) and the North Sea Basin (reference: North Sea coast line). Additional geological features are the Triassic Glueckstadt Graben, the Danish-Norwegian (Northern Permian) Basin, the Harz Mountains (HZ), the Bramsche Massif (BM), and the Variscan Orogen. As geographical features Northrhine-Westfalia (NW), Pompeckj Block (PB), The Netherlands (NL), Denmark (DK) and Poland (PL) are marked. 


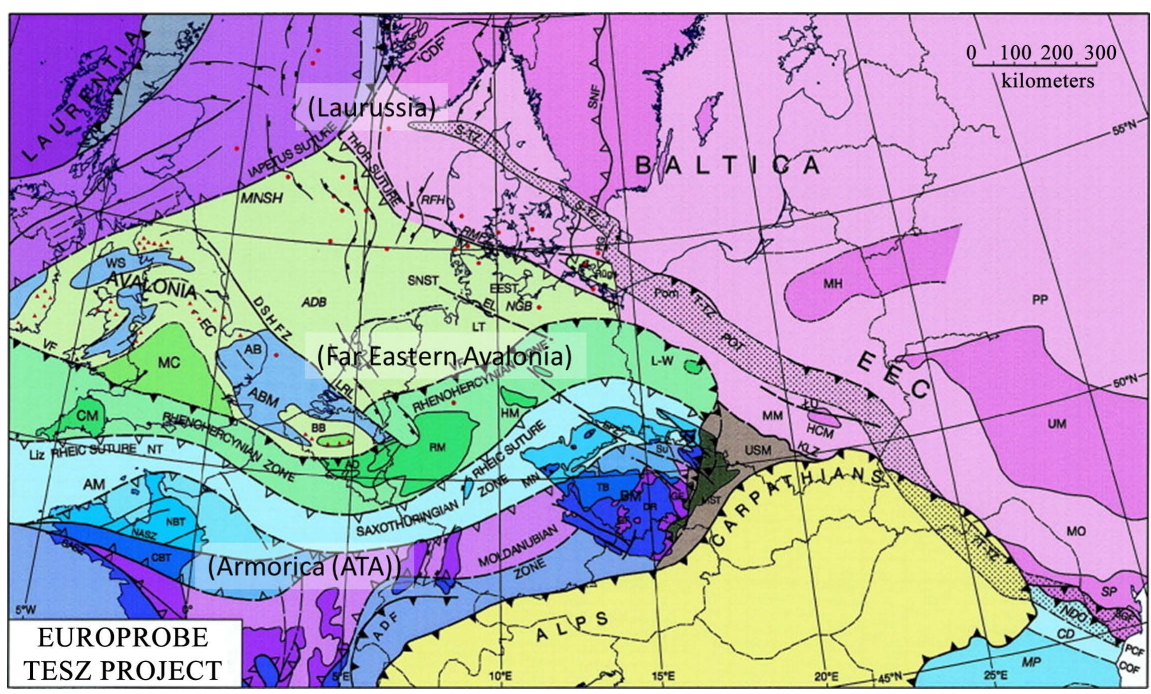

Figure 2. Map showing the distribution of crustal blocks and Paleozoic deformation belts in Central Europe, modified after [1]. EEC East European Craton, S-TZ and T-TZ Sorgenfrei-Tornquist and Tesseyre-Tornquist Zones as parts of the TESZ (Trans-European Suture Zone), ATA Armorican Terrane Assemblage, BB Brabant, HM Harz Mountains, RM Rhenish Massif.

The collision enforced the development of an Upper Carboniferous Basin on top of Eastern Avalonia due to the vertical upload of tectonic nappes of the Rhenohercynian belt and the deformation of the basin interior through horizontal compression [8]. The evolution of the Variscan Deformation Front (VDF) of present-day Northern Germany [8] will be one of the main topics of this paper in view of geological and geophysical (reflection/refraction seismic and magnetotellurics) anomalies. The geophysical gravimetric and magnetic potential routines provide essential contributions as well, e.g. for the investigation of the evolution of the North German Basin [9] [10]; however, they are less important here since the properties of younger than Variscan processes are masking significantly the petrologic and tectonic effects of deeper and older geodynamic events as shown by the integrative interpretation of the Bramsche anomalies [11] [12]. This paper briefly describes the plate tectonic history of Eastern Avalonia, its (Devonian to) Lower Carboniferous sedimentary cover by applying the magnetotelluric method as an eye-opener [13] that includes the investigation of the Bramsche anomaly as a dominant feature within the southwestern sector of the inverted Lower Saxony Basin as well, the Variscan Deformation of the Upper Carboniferous subvariscan basin fill by applying 3D-seismic [14] and how the development of the Harz Mountains and its root [15] [16] may be related to the evolution of the shape of the Variscan Deformation Front. Comparing Variscan features with Alpine ones may support the conclusions of this paper.

\section{Avalonia and the Variscan Orogeny}

Based on the analysis of a limited number of deep well rock samples the Paleozoic subsedimentary crust of northern Central Europe is assumed to be a part of 
the former Avalonia microcontinent. This microcontinent is fragmented today in an American/Laurentian and European (Eastern) part from which the Dutch/ German segment is defined as Far Eastern Avalonia. Petrologic and tectonic properties of this ancient terrane certainly controlled the geological development of Northern Germany during later phases from late Paleozoic to present times, which include regional reactivation of extensional, compressional and transtensional/transpressional faults, heat flow fluctuations and rock melting events, pressure and temperature related rock metamorphism, different rigid, brittle or ductile behavior as well as varying local and regional subsidence and inversion histories and the related deposition of environment dependent sedimentary facies and their occasional erosion.

The birth of Avalonia with the break-up of the northern Gondwana margin from the Late Cambrian onwards (Figure 3) subsequently shaped oceanic partitions [5] [6] [7]. Biogeographical data and paleomagnetic restrictions as well as geological indications approve the presence of three Gondwana-derived microcontinents which were later involved in the Variscan collision: Avalonia, North Armorica (Franconia and Thuringia), and South Armorica (Central Iberia/Armorica/Bohemia), all separated by small oceans. It is the short-lived Rhenohercynian ocean (and not the Rheic) whose opening and closure ruled the evolution of the Rhenohercynian foldbelt in Germany [17] (Figure 4). Palaeomagnetic and faunal data indicate that Gondwana was near Laurussia during the Devonian and Carboniferous periods, with fragments of Bohemia and other parts of the Armorican Terrane Assemblage (ATA) scattered between. In late Ordovician Avalonia

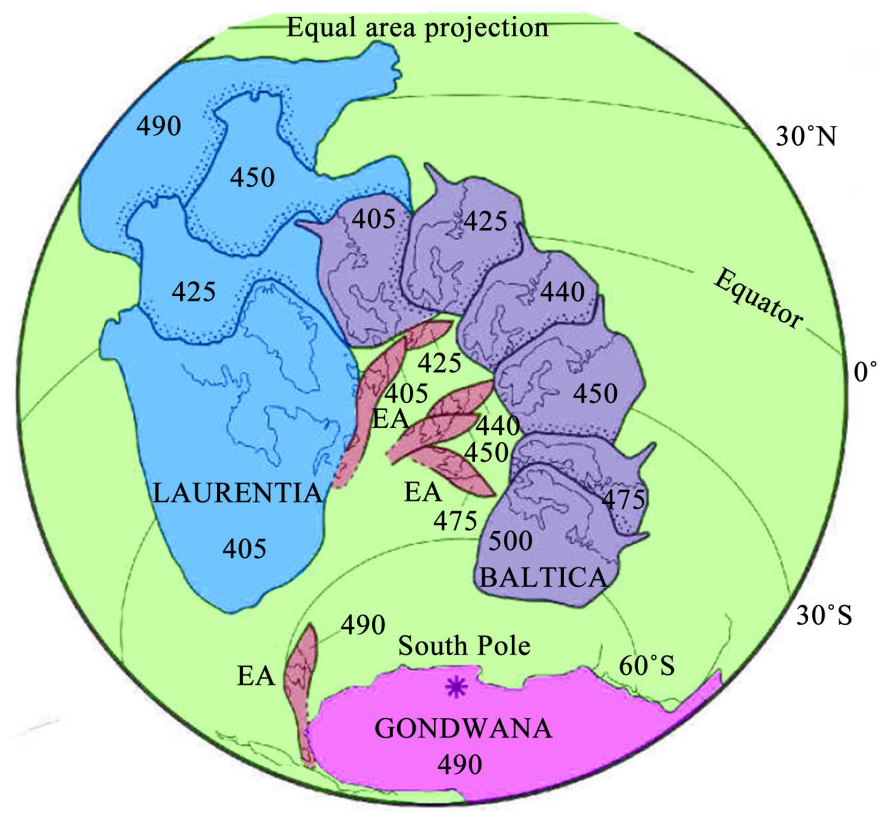

Figure 3. Drift of Baltica, Laurentia and Eastern Avalonia (EA) during the Early Paleozoic [18] Ages are in Ma. Note Baltica's anticlockwise rotation after 520 Ma. Gondwana-derived further terranes arriving during the succceding Variscan evolution are not shown. After [19]-[24], modified in color. 


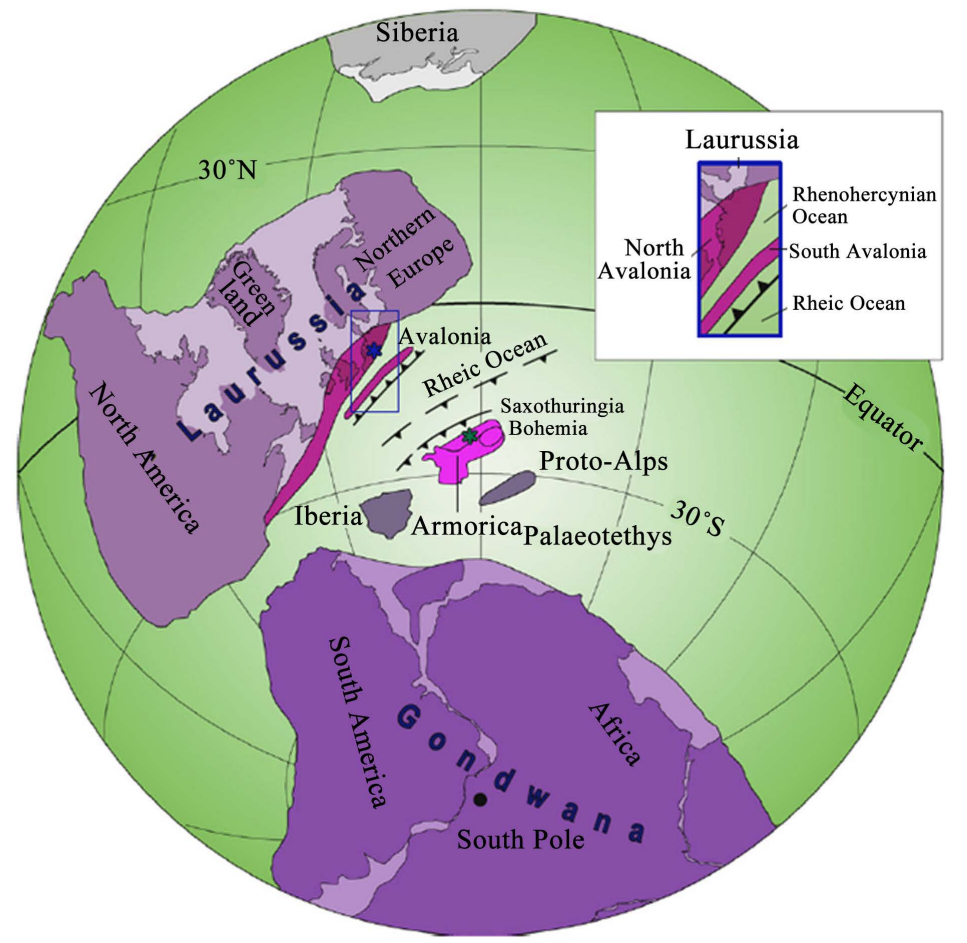

Figure 4. Plate-tectonic reconstruction for the Late Devonian to Early Carboniferous. Black star: Position of the autochthonous Rhenish Massif (Rheinisches Schiefergebirge). Green star: Source area of the nappe units in the south east of the Rhenish Massif (Rheinisches Schiefergebirge) after [17], colors modified.

accreted onto Laurussia (Baltica) along the Trans-European Suture Zone (TESZ), and the Armorican Terrane Assemblage (ATA) later in early Carboniferous after they amalgamated during Late Devonian-Early Carboniferous time. Laurussia and Gondwana finally collided at around $320 \mathrm{Ma}$ to form the super-continent Pangea.

Indications evolve that the Eastern Avalonia basement below Northern Germany includes at least two terranes: the European remnant of the paleocontinent Avalonia, and what is called the paleocontinent fragment Far Eastern Avalonia; the latter is only occasionally observed in the few deep boreholes into the Heligoland-Pomerania Deformation Belt, in Southern Denmark and Northeast Germany, with limited available indirect data in between indicating only Proterozoic basement and no Caledonian deformation. For Far Eastern Avalonia a similar paleogeographical history is postulated as for Avalonia itself, with rifting from Gondwana, collision with Baltica and subsequent deformation between the late Ordovician and latest Silurian. The Avalonia might be interpreted as an "Avalonian Terrane Assemblage" with cratonic cores and small short-lived oceans like the Armorican Terrane Assemblage probably is [25].

According to [17], the geodynamic development of (Far) Eastern Avalonia at the southern margin of Laurussia is documented by the evolution of the grain sizes of the pyroclastic deposits. During the Lower Devonian typical fall out and 
ignimbrite deposits materialize, often consisting of coarse-grained particles. In the Middle Devonian, extremely fine grained ash fall was deposited, which indicates the opening of the Rhenohercynian Ocean [26]. As a result Avalonia split up into a northern and a southern segment-North and South Avalonia (Figure 4). Because of the increasing distance, the grain size of the pyroclastic fall out deposits decreases. The grain size of the Visean volcanic ashes increased again as a result of the closing of the Rhenohercynian Ocean. The existence of South Avalonia is verified by the detrital zircons in the Ruhla Crystalline complex of the Mid-German Crystalline zone (MGCZ), which imply two different source areas [27]. The northern part of the Ruhla Crystalline complex displays a provenance in Avalonia, whereas the southern part has a provenance in Armorica.

The division into Variscan oriented North and South Avalonia adds two extra segments, but with different orientation to the TTZ related subset, and yields to an assemblage of at least four different terranes for the Avalonian subsurface of Northern Germany. Avalonia may therefore contain two main sets of tectonic lineaments, one subparallel to the TTZ (NW-SE), including the Hercynian directed fault pattern (e.g. the generally at least in two sectors divided WE-structured inverted Mesozoic Lower Saxony Basin), and the other one subparallel to the Variscan foldbelt, including the Rhenish directed fault pattern (NE-SW) (e.g. Triassic Glückstadt Graben, see below). Due to rotational moves of plates in course of their continental drift plate internal lineament directions of today are probably only randomly identical with those of the past. Generally they differ. For the occasional reactivation of "frozen" directions adequate directed plate tectonic forces had to be present.

\section{Autochthonous East Avalonian Crust/Magnetotellurics (MT)}

After consolidation of Avalonia with Baltica and Laurentia and before a further set of microcontinents approached, (Far) Eastern Avalonia became a continental shelf area covered by marine sediments during Late Devonian and Early Carboniferous times [2]. In the North German Basin these sediments are covered by younger sediments of Upper Carboniferous/Permian to Quaternary age that are in total up to $10 \mathrm{~km}$ thick. At this depth the resolution of reflection and refraction seismic data is very poor, gravity and magnetic methods are ambiguous and wells have been drilled through the Late Devonian and Early Carboniferous strata only at the edge of the Basin. A geophysical method which owns the potential to probe the deep subsurface is magnetotellurics (MT) which delivers a vertical section of electric conductivity of the subsurface down to crustal depths.

MT is a passive electromagnetic method relying on natural geomagnetic field variations, principally originating from the time-varying solar wind (for periods $\mathrm{T}>1 \mathrm{~s}$ ) and the radiation of thunderstorm lightnings (for $\mathrm{T}<1 \mathrm{~s}$ ). These fields penetrate into the subsurface and induce electrical currents within the Earth (see e.g. [28]). According to the so-called skin effect, these signals decay exponentially with longer periods reaching deeper parts of the Earth, with a scale length 
(penetration depth) proportional to the square root of period and electrical resistivity (inverse of electrical conductivity). Especially good electrical conductors of sedimentary layers are often successfully recognizable. In the case of the North German Basin, periods of up to several thousand seconds have to be recorded. As a passive method, MT is susceptible to technical noise which limits its application near settlements and technical installations (pers. comm. by Heinrich Brasse).

Magnetotelluric (MT) data carry information about highly conducting layers in pre-Permian sediments of the North German Basin, and present a way, how seismically poorly resolved parts of the basin can be geophysically characterized and geologically interpreted [13]. Depth and lateral distribution of the conducting layers are used to outline the sedimentary facies development of the Lower Carboniferous in a regional context, to allocate pre-Westphalian source rocks, to clarify the location of the Caledonian wedge in relation to the Baltic shield, to image the internal structure of the Variscan Front at greater depth, and to evaluate the presence of magmatic intrusions. All these single contributions to the interpretation of the geological evolution of the North German Basin clearly demonstrate that the magnetotelluric method is a valuable geophysical tool with the potential to improve the understanding of the geological history of a region significantly.

In this case, the two following observations became important that resulted in the acquisition of measurements of $226 \mathrm{MT}$ sites of 13 wide-scales, magnetotelluric surveys in 1992-2004 (Figure 5). There are at least two principal conductors

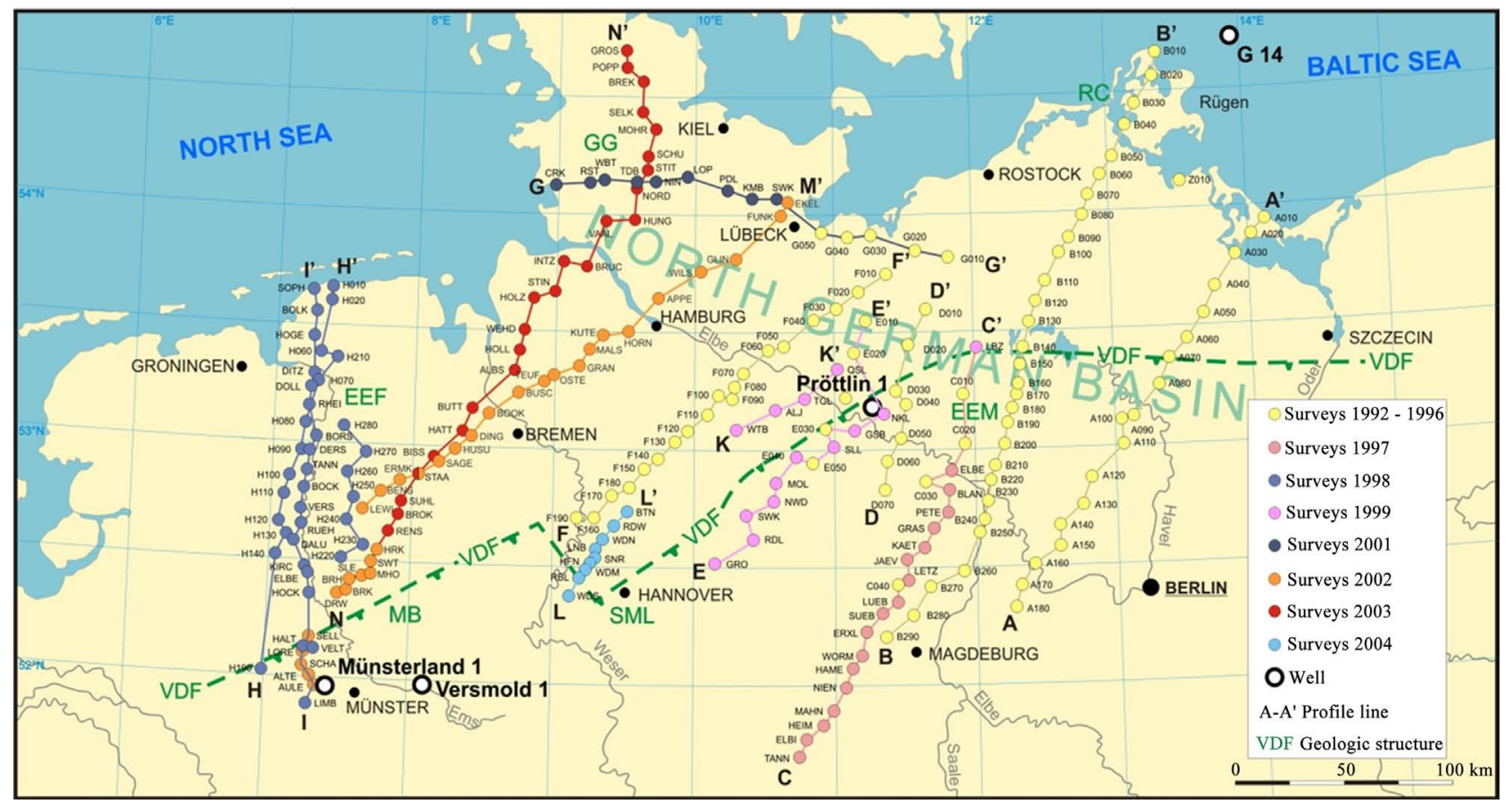

Figure 5. Map of magnetotelluric sites in the North German Basin, which are subdivided into the different profile lines A-A' to N-N', measured in 1992-2004 [37]. EEF: Emsland-East Friesland; EEM: East Elbian Massif; GG: Glückstadt Graben; MB: Massif of Bramsche; SML: Steinhuder Meer-Lineament; VDF: Variscan Deformation Front interim proposed by [13]. 
in the succession-highly coalified bitumen-rich and sulphide-rich black shales [29]-[34]. In earlier magnetotelluric surveys a highly conductive layer at greater depth was already detected in some regions of the North German Basin. The surveys allow an enhanced understanding of the regional distribution of potential pre-Westphalian gas source rocks and of the lithofacies and tectonic pattern of the pre-Permian substratum. Based on these 13 profiles a regional map of specific rock properties with geological controls can be provided based on the interpretation of the resistivity-depth distribution. Results from three of these surveys are geologically interpreted and presented here: Glückstadt Graben (Figure 6) and Emsland-Friesland area (Figure 7) as well as Bramsche Massif for a special purpose (see further below). The 2D-MT models were achieved with the inversion code of [35], yielding a smoothed image of electrical conductivity (or resistivity) distribution.

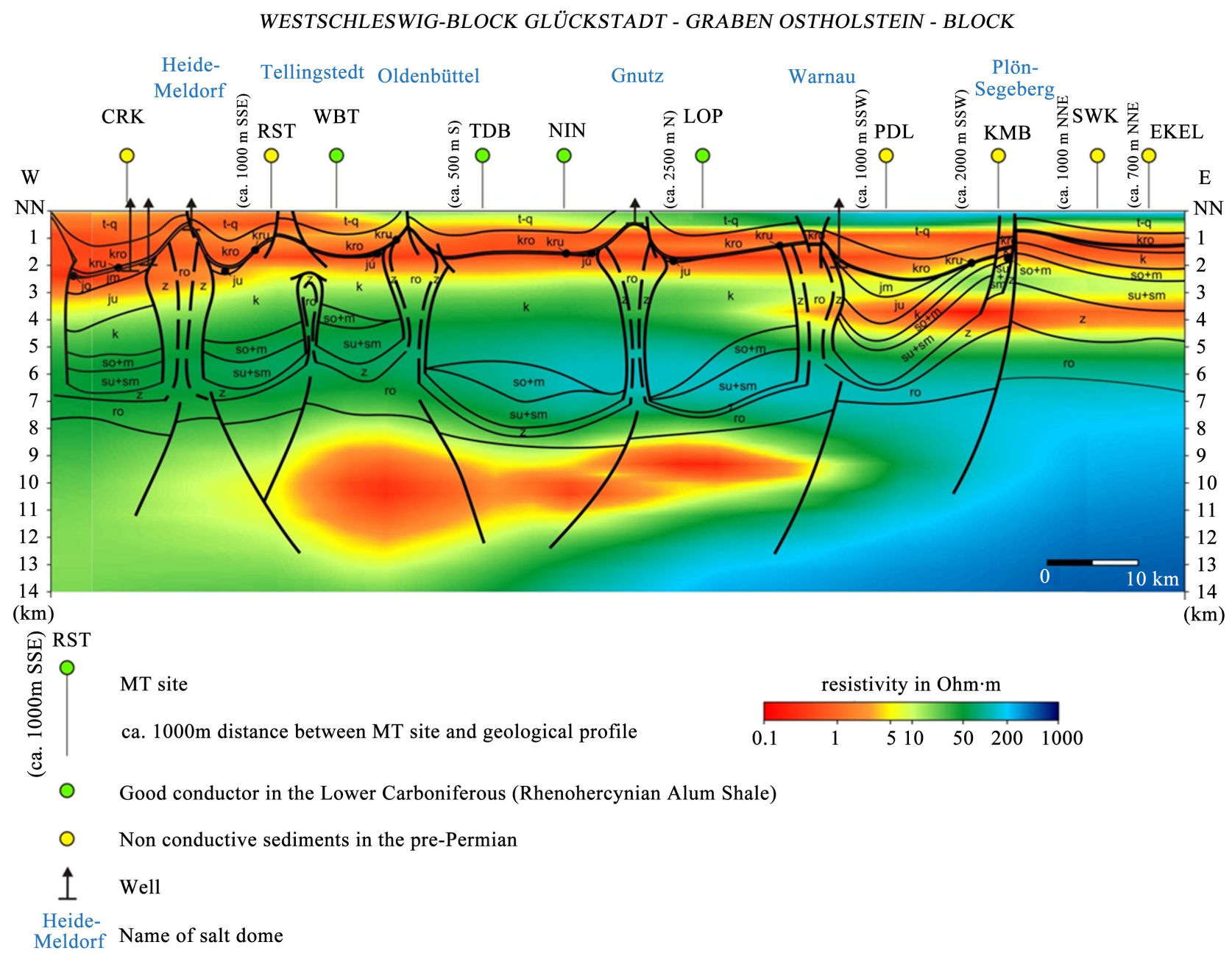

Figure 6. Glückstadt Graben MT, profile G-G' [13] [37]. Integration of the Glückstadt Graben (GG, Figure 6, profile G-G') 2D MT model (top) into a geologic-geophysical section (redrawn and completed after [40] Baldschuhn et al. 1996): q-t = Quarternary-Tertiary, kro = Upper Cretaceous, kru = Lower cretaceous, jm = Dogger (Middle Jurassic), ju = Lias (Lower Jurassic), $\mathrm{k}=$ Keuper (Upper Triassic), so + m = Upper Buntsandstein and Muschelkalk (Upper Lower and Middle Triassic), sm + su = Middle and Lower Buntsandstein (Lower Triassic), z = Zechstein, ro = Upper Rotliegend. 


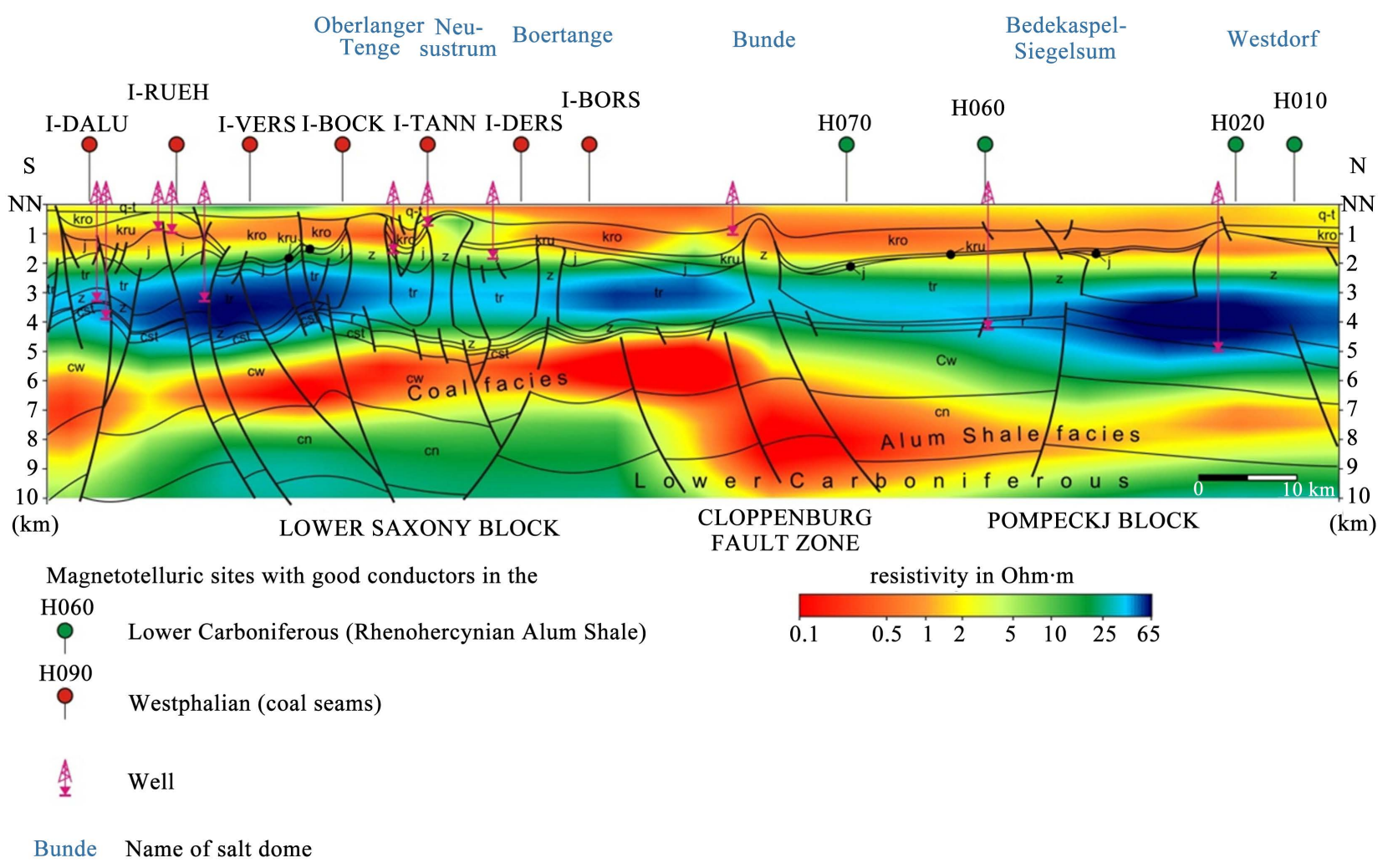

Figure 7. Emsland MT, composed profiles H/I-H'/I' [13] [37]. Integration of the Emsland (EEF, Figure 6) 2D MT model (top) into a geologic-geophysical section, composed profiles H/I-H'/I' (redrawn and completed after [40] Baldschuhn et al. 1996): q- $\mathrm{t}=$ Quarternary-Tertiary, kro = Upper Cretaceous, kru = Lower cretaceous, $\mathrm{j}=$ Jurassic, $\mathrm{tr}=$ Triassic, $\mathrm{z}=$ Zechstein, $\mathrm{r}=$ Rotliegend, cst = Upper Carboniferous (Stephanian), $\mathrm{cw}=$ Upper Carboniferous (Westphalian), $\mathrm{cn}=$ Upper Carboniferous (Namurian). The location of the geological cross section and the measured MT profile are not identical because it was planned to bypass salt structures with the MT measurements.

The MT results may present predominantly an indication for the Lower Carboniferous facies distribution. Paleogeographic maps of the North German Basin in times of the Lower Carboniferous will possibly have to be modified, because the black shales of the Stillwater facies most probably extend much further to the north than previously suggested (Figure 8). Furthermore, a connection between the Rhenohercynian Culm facies realm and the so-called Bowland shale facies or equivalent areas of the southern North Sea and Central England via the "East Friesland Basin" cannot be excluded. The Lower Carboniferous sedimentation area is characterized by typical horst and graben structures with corresponding patterns of carbonate and black shale facies distribution. The MT results suggest that the Cleaver Bank High of the southern North Sea and the eastern Netherlands may extend into the Lower Saxony Block and that the Northwest German Basin may form a genuine part of the Lower Carboniferous large-scale horst and graben system [36] [37]. This large-scale horst and graben system could have had a precursor in the tectonic framework of the underlying Devonian strata. The depositional environment of the Middle and Late Devonian was very similar to the Lower Carboniferous with essential carbonate sedimentation [4]. However, 


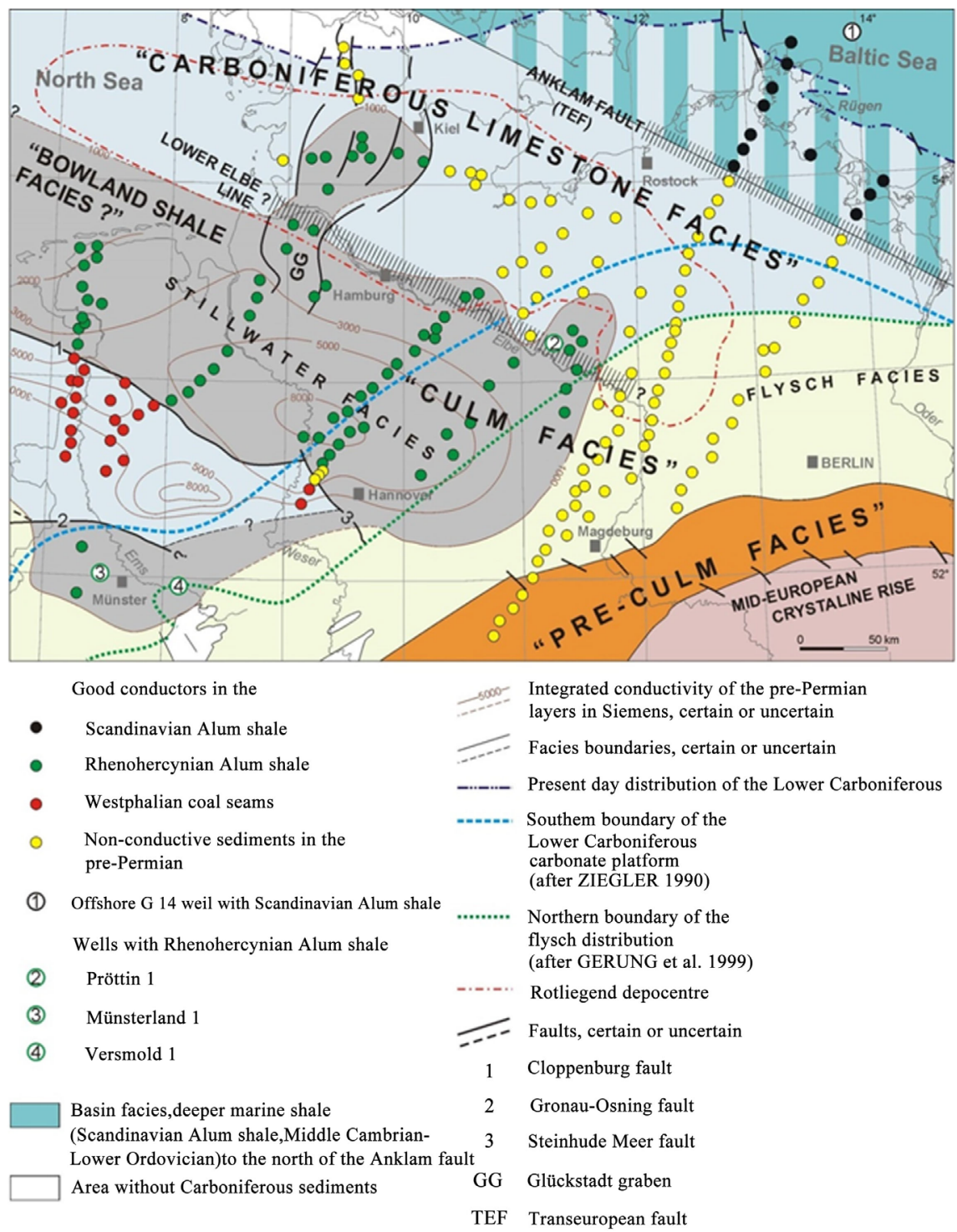

Figure 8. Simplified map of the integrated electrical conductivity of the deep pre-Permian conductor combined with the regional distribution of the Lower Carboniferous stillwater ("Culm") and carbonate facies of the North German Basin, derived from magnetotelluric measurements [13] [37]; the values of the integrated conductivity are taken from 1D-models after [33] [42] [45] [46] [47] for the western part and from [48] and [49] and modified after [46] for the eastern part.

sedimentation of clastics has also been reported. The NW-SE striking Caledonian accretionary wedge, which was eroded down to its metamorphic levels during the Silurian and Early Devonian [2] [3], became the basement of the overlying sedimentary basin. The NW-SE running framework of the Caledonian basement, reactivated in later times during the Lower Carboniferous, probably affected the depositional environment of the Devonian as well. Therefore, Devonian carbonates can predominantly be expected below the Lower Carboniferous carbonates, and Devonian shales mainly below Lower Carboniferous shales.

The MT measurements record the conductivities of the combined Lower 
Carboniferous and Devonian layers. In areas, where shales are dominating, the underlying Caledonian basement represents most likely the seismic refraction horizon Ur [13] [38]. In areas with a thick pile of high velocity carbonate layers, the Ur-refractor is probably caused by the velocity increase at its top. Since the positions of the presented MT profiles do not coincide with the ones of the old refraction profiles [38], a direct comparison is unfortunately not possible. Local granitic intrusions of Permian age may affect both seismic refraction waves and MT recordings. Taking an average basement depth of $12 \mathrm{~km}$ for the central part of the North German Basin, reference [39] concluded, that the anomalies of the reduced Bouguer gravimetric and the observed magnetic fields can be better explained by the variation of rock density and susceptibility inside the basement than by an appropriate basement topography. Therefore, rock property variations of the NW-SE structured Caledonian basement may also have a minor effect on seismic refraction and MT recordings.

The Triassic Glückstadt Graben (GG in Figure 6) is located in the deepest part of the North German Basin, where the base of the Zechstein attains depths of more than $10 \mathrm{~km}$. Seismic profiles show a series of high amplitude reflections below the reflection from the base of the Zechstein, that most likely do not belong to the underlying Rotliegend. According to current knowledge, the Rotliegend in the basin center is predominantly composed of halites and shales [41], which were squeezed into the abundant large salt walls during the Mesozoic and Tertiary tectonism. Only a relatively thin layer of clastics and volcanics remains. These lithologies are present throughout the North German Basin and do not show the seismic signature comparable to that recorded below the Triassic Glückstadt Graben. Therefore, since the recorded seismic reflections appear to be unique for North Germany, MT measurements were carried out at 10 sites on an east-west oriented profile across the total width of the Glückstadt Graben (Figure 6) with the objective of improving the understanding of the sedimentary strata in the deepest part of the basin. The modelling results [37] show, that the central part of the graben is characterized by a good MT conductor at depths of approximately deeper than $10 \mathrm{~km}$, and that this conductor is missing on the adjacent graben flanks. The calculated depth is coincident with the depth to the base of the Zechstein. The Kupferschiefer facies of the basal Zechstein sequence may be a good electrical conductor; however, its thickness of a few decimeters is insufficient for the layer that could represent the observed conductivity. Therefore, thicker organic rich layers have to be assumed. Based on observations from nearby drill holes, Lower Carboniferous black shales can be expected within this specific area of the graben. Within the adjacent East Holstein area seismic reflections and refractions point to the presence of Lower Carboniferous carbonates on the flanks of the graben. This observation supports the assumption that the Glückstadt Graben has a Paleozoic precursor and represents only a reactivated tectonic feature that was already active during the earlier stages of the basin development.

MT results from the Emsland and East Friesland profiles (EEF in Figure 7) 
are of particular interest for the understanding of the regional distribution of Lower Carboniferous black shales in the western part of the North German Basin. MT models [36] [42] suggest that the good conductor observed in the area of the Pompeckj Block at depths of 7 to $9 \mathrm{~km}$ may be correlated with these black shales. This deep conductor is missing underneath the more mobile Lower Saxony Basin Block to the south, but along the Cloppenburg fault zone is replaced by another conductor at shallower depths between 5 and $6 \mathrm{~km}$. As a regional feature this conductor can be correlated with Westphalian coal seams [40] that were strongly coalified by deep subsidence during the Jurassic and Lower Cretaceous and then uplifted during the Upper Cretaceous inversion of this block. Highly coalified coals (anthracite) were mined in the nearby Ibbenbüren district until 2018. The absence of the deeper conductor in the southern part of the profile, which would be indicative of black shales within the Lower Carboniferous strata at about 7 to $9 \mathrm{~km}$ depth south of the Cloppenburg fault zone, can be explained by the "Lower Saxony Carbonate Platform" as a facies equivalent of the clastic sediments [36] (Figure 8 and Figure 9). According to [43] fluid inclusion analyses of vein cements demonstrate that hydrothermal fluids transported inorganic $\mathrm{CO}_{2}$ into a Late Permian Zechstein reservoir within the Lower Saxony Basin, where it mixed with minor amounts of TSR (thermochemical sulfate reduction) -derived organic $\mathrm{CO}_{2}$. The likely source of inorganic $\mathrm{CO}_{2}$ is the thermal decomposition of deeply buried Devonian (and Lower Carboniferous) carbonates, which presence may therefore indirectly confirmed at this location. The good conductor on the Pompeckj Block in the northern part of the profile is located beneath Rotliegend gas fields of the "Ems Estuary" production district at

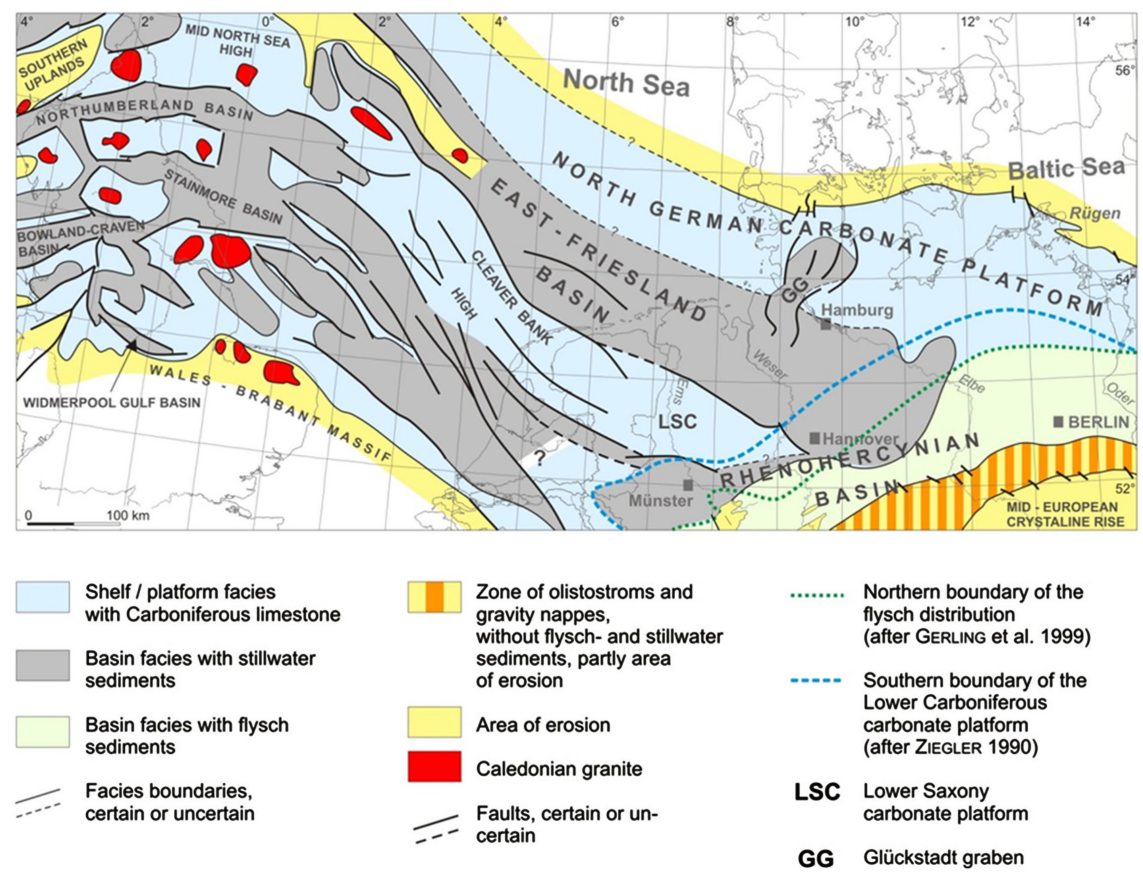

Figure 9. Tectonics and paleogeography of the Lower Carboniferous from England (after [50]) to Northern Germany modified after [36] in [13]. 
the German-Dutch border [44]. Its presence correlates with gas and isotope geochemical indicators demonstrating that Rhenohercynian sapropelic Alum Shales were a significant source for these gas fields (Figure 10).

The distribution of Carboniferous carbonates in The Netherlands may be more complex than shown here since the results of the classified deep Key-well UHM-02, Onshore the Netherlands [51], have not been incorporated in this map yet.

In the early years of electromagnetic deep sounding the west-east running North German Conductivity Anomaly was detected [52] [53] [54]. It refers to the reversal of induction arrows (as a graphical representation of the tipper transfer function, the ratio of vertical to horizontal magnetic field variations) at the northern and southern margins of the North German Basin. Its origin has remained ambiguous. Explanations encompass a deep-crustal or even mantle source or subsidence of sediments in the center of the basin. The main result of a recent study as presented by [55] is that the reversal of induction arrows can largely be explained by the resistivity contrast between crystalline basement and sedimentary basin fill. Beneath the basin, a moderately conductive upper mantle is modelled (although not very well resolved) which may reflect the thinning of the lithosphere as implied by seismic tomography. As the main anomalously inductive effect is primarily explained by the basin edges and numerous other anomalies exist inside the basin, reference [55] suggest not using the term "North German Conductivity Anomaly" any longer. Therefore, an influence by the "Avalonian Terrane Assemblage" appears possible, since the trend of the conductivity anomaly may mirror the trend of through a hercynian fault system (roughly NW-SE-directed) segmented generally west-east running inverted Lower Saxony Basin further south. Indeed, the extension of the conductivity anomaly towards

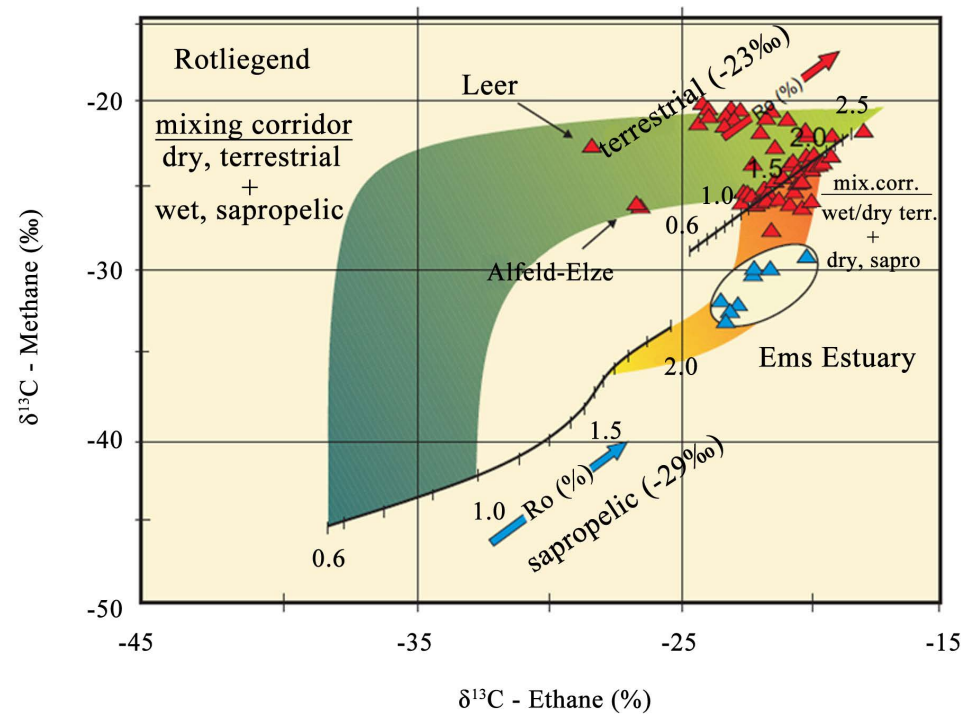

Figure 10. Gas and isotope geochemical indicators of methane und ethane of some North German Rotliegend gas fields (after [44]) with mixing corridors of dry terrestrial with wet sapropelic gases (green) and of wet/dry terrestrial with dry sapropelic gases (orange) shown, pointing to a variability of source rocks and maturities in this region. 
Poland by crossing different tectonic units from the Variscan foreland to the Rhenohercynian belt [54] [56] would suggest that the coincidence of both trends has a common deeper Avalonian source or its origin lies below in the Earth's mantle (see also [53]).

\section{Variscan Deformation Front (VDF)}

After the deposition of Late Devonian and Early Carboniferous marine sediments on the Far Eastern Avalonian basement the area became under stress due to the approaching Variscan Orogen from the southeast. Depending on the reactions of structural features below the sedimentary cover was particularly overthrusted, folded and faulted.

This process was worked out by [8] in detail. They generally discussed the formation of the Variscan Deformation Front (VDF) and identified two types of basins that developed in front of the prograding Variscan Orogen: 1) close to the orogen flexural basins 2) further north, in the outer foreland, wrench induced basins developed. The Variscan Deformation Front (VDF) is understood as finally formed during the Stephanian (Figure 11). South of the pre-Variscan Brabant Massif the Variscan Deformation Front is narrow and thrust dominated. To the East, a fold belt advanced with upright folds and spreading far to the NW. The VDF is abruptly ceased in the Northeast by the Osning Transfer Fault Zone, where it is offset some $100 \mathrm{~km}$ towards the Southeast. According to [8], within the Lower Saxony Basin and the adjacent Pompeckj Block to the north, no Variscan Orogenic folding has been observed so far. This foreland area was subjected to transpressional and transtensional wrench-type deformation along the WNW-ESE and SSW-NNE trending (hercynian) faults of the Central European Shear Zone. The Variscan Deformation Front (VDF) itself forms the northern boundary of the Variscan fold belt as a $10-20 \mathrm{~km}$ wide zone where a distinct orogenic folding is completed. Consequently, there emerges only very narrow space for the fold belt of the Subvariscan Zone northwest of the Harz Mountains. Due to the different shortening of the Variscan Orogen in the Rhenish Massif and the Harz Mountains, respectively, the Osning Fault Zone is seen as a transfer fault active during Late Carboniferous orogenic movements.

In contrast, [57] postulated a continuation of the VDF into the Lower Saxony Basin and Pompeckj Block. However, [58] contradicted this opinion by investigating 3D seismic surveys SW of the city of Bremen. He interpreted the weak folding of the pre-Permian there as being formed by Variscan faulting and not by orogenic folding.

Differently to [8], but similar to [57] reference [14] proposed a quite different trend of the VDF north of the inverted LSB, having a much larger 3D-seismic volume available than [58], who interpreted only a small 3D seismic dataset. They unraveled regional Intra-Carboniferous reflections in 3D seismic data of NW Germany and suggest that the Variscan deformation extends into the area of the Pompeckj Block north of the Lower Saxony Basin (LSB). Although subtle in 


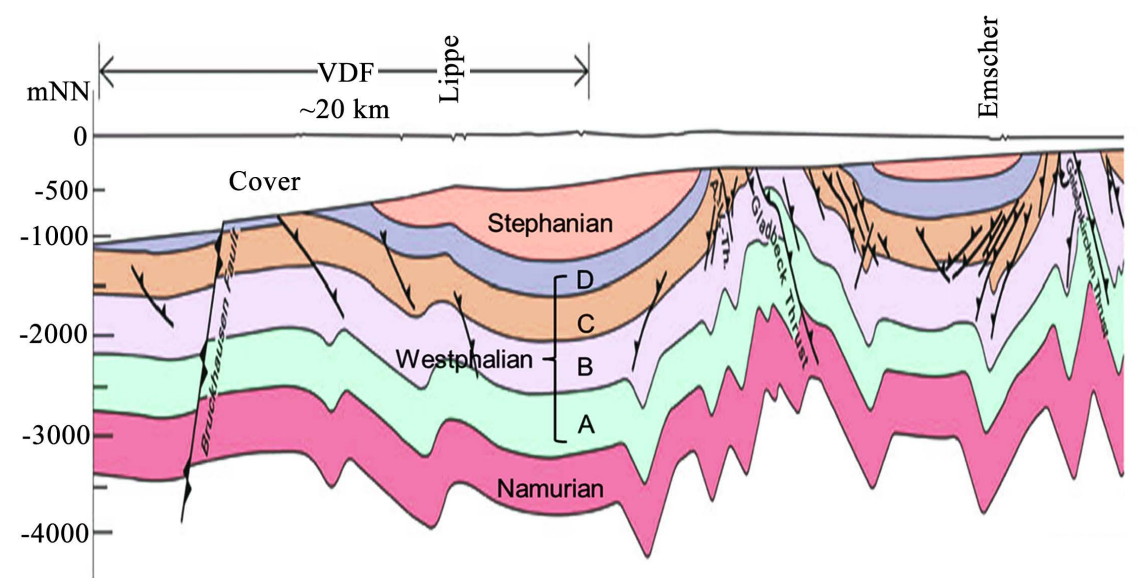

(a)

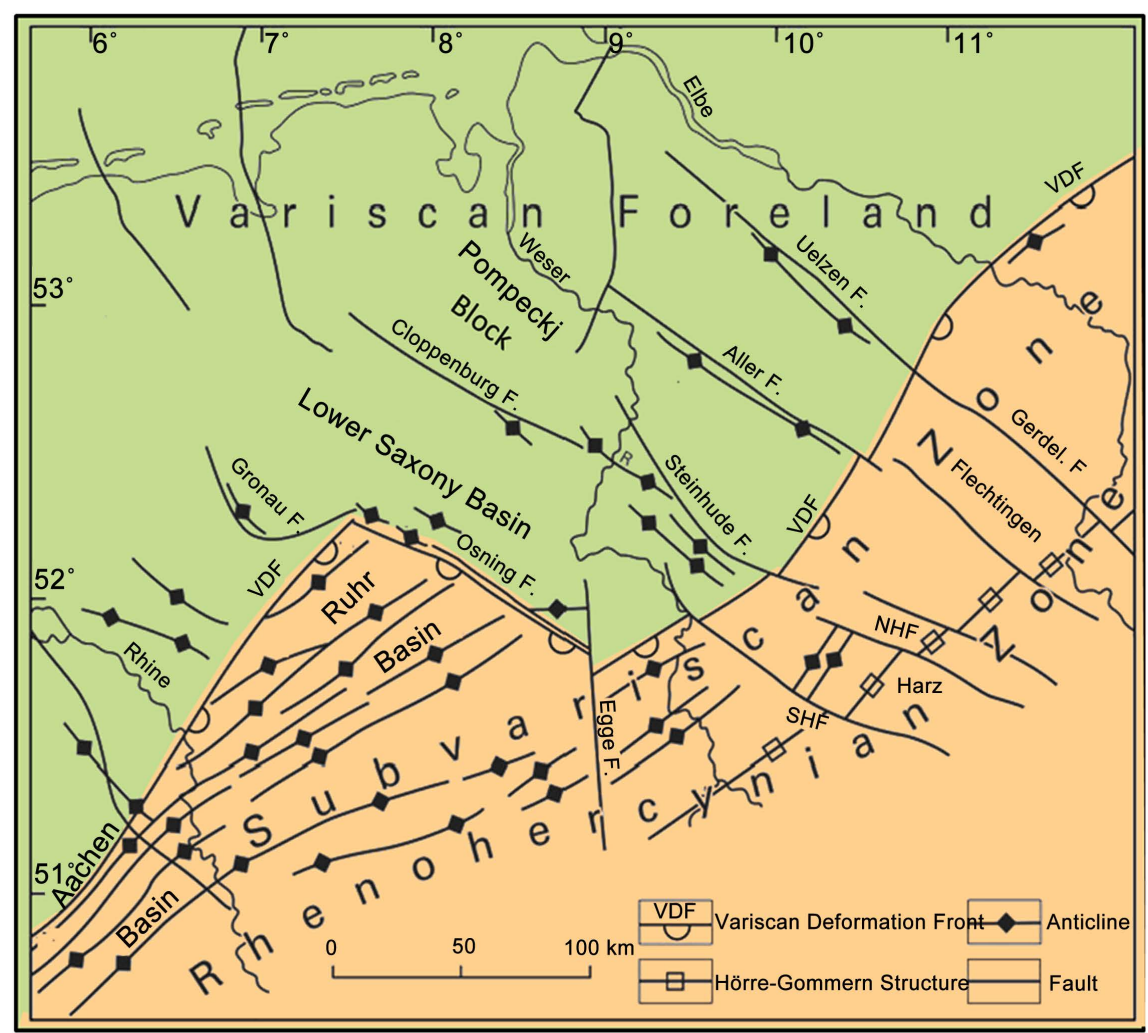

(b)

Figure 11. (a) The Variscan Deformation Front (VDF) in a sketched cross-section through the western Ruhr Basin, and (b) Structural elements of the Variscan Foreland and the Variscan Orogen in Northwest Germany after [8].

some areas due to low signal/noise ratio and reactivation/overprint by younger tectonics, an almost regularly spaced system of NE/SW trending folds and NW/SE trending faulted highs (similar to the Osning Fault) could be mapped. Such findings may support the assumption that the Carboniferous beneath the Lower Saxony Basin is also folded. 


\section{Variscan Foreland Basin vs. North Alpine Foreland Basin}

The abrupt change of structural styles as observed in the Variscan Foreland Basin in Northwest Germany-independently which trend of the VDF is preferred - seems plausible, since a similar abrupt change of tectonic patterns has been recognized within the younger North Alpine Foreland Basin (Molasse Basin) as well. Southwest of the narrow Lake of Constance Basin a compressional regime prevails in Switzerland, on the northeastern side in Southern Germany only extensional structures exist in front of the folded Molasse band (Figure 12).

Just west of the Lake of Constance Basin in the Hegau area, at least 85 volcanic pipes of Miocene age ( 9 - $15 \mathrm{Ma}$ ), containing a.o. Olivine-Melilitite minerals, have been identified so far (Institut für Geographie, Justus Liebig Universität Giessen), sourced partially from upper mantle rocks $90 \mathrm{~km}$ deep $\left(27 \mathrm{kbar}, 1160^{\circ} \mathrm{C}\right.$ to $1200^{\circ} \mathrm{C}$ ) (Figure 13). This may suggest that the narrow zone between the Swiss and German parts of the North Alpine Foreland Basin is deeply rooted and may have also affected the evolution of the transition zone between the Western and Eastern Alps close to this location. The German/Austrian Eastern Alps are acting predominantly as a vertical load by bending the foreland, the Swiss Western Alps on the other side of Lake of Constance as vertical load and horizontal push. This horizontal push activated presumably detachment levels within the underlying salt rich Triassic strata, enabling folding of the interior of the Swiss Molasse Basin and the adjacent Jura Mountains. In terms of the Variscan Deformation Front discussion the folded Jura Mountains and the Swiss Molasse would lie inside of the to be named Alpine Deformation Front. Detachment levels may similarly exist within the Variscan Foreland Basin as well, as already proposed by [57], since ductile detachable Lower Carboniferous stillwater sediments are at least present in the foreland grabens.

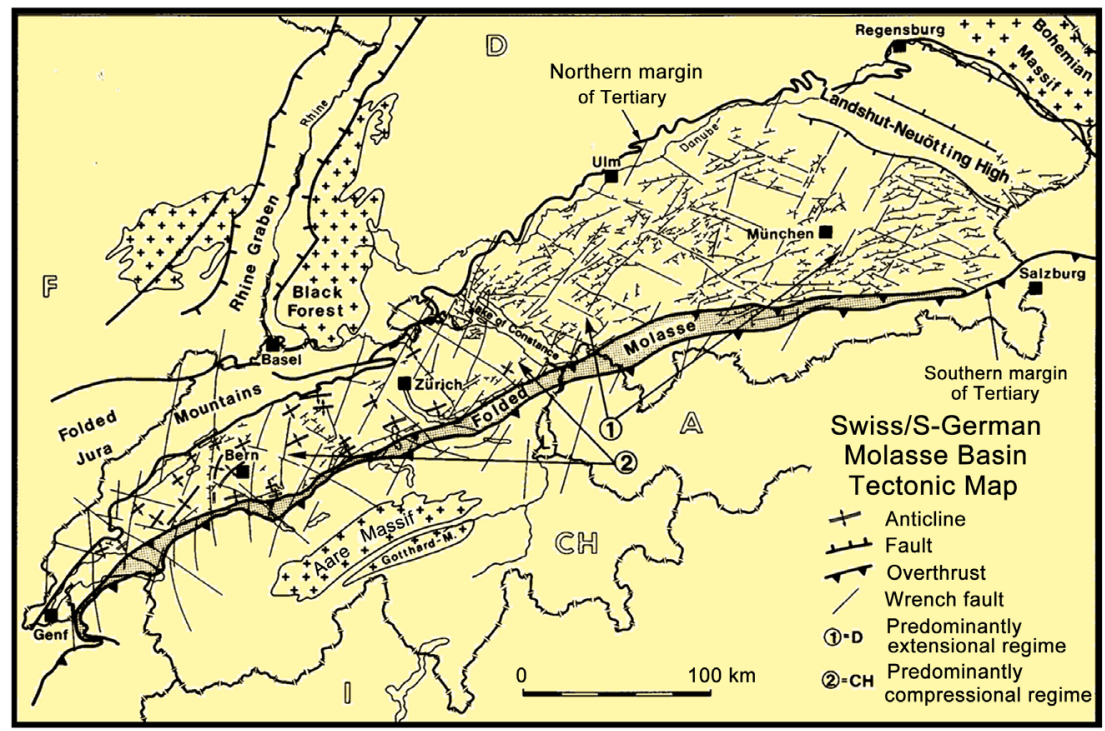

Figure 12. Tectonic map of the Swiss/German Molasse Basin (North Alpine Foreland Basin) showing compressional structures in Switzerland and extensional ones in Germany, after [59]. 


\section{Geology of Baden-Württemberg}

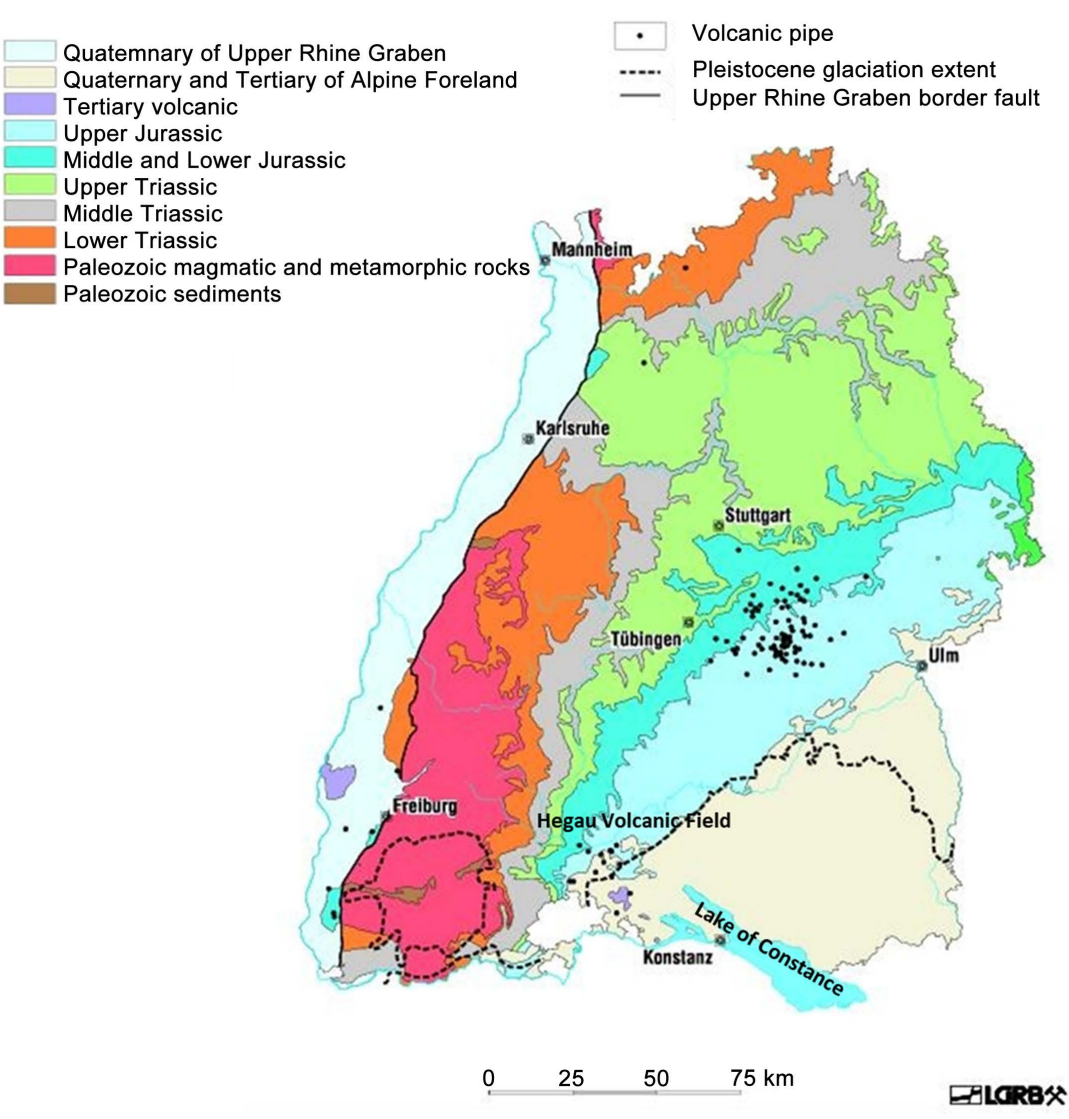

Figure 13. Geology of the Federal State of Baden-Württemberg with Lake of Constance and the Hegau Volcanic Field after Landesamt für Geologie, Rohstoffe und Bergbau Baden-Württemberg 2021, modified.

\section{Lower Saxony Basin (LSB) vs. Vienna Basin (VB)}

The presumed Devonian/Lower Carboniferous Lower Saxony Carbonate Platform (LSC) is directly underlying the oblique deposition center of the Upper Carboniferous Variscan Foreland Basin as well as the sedimentation and tectonic center of the inverted (Mesozoic) Lower Saxony Basin with the Bramsche Massif (Anomaly of Bramsche) therein at a significant central position (Figure 14). The areal coincidence of these four geological features is remarkable and points to a cause below them. It appears to be related to the local properties of the EastAvalonian crust. However, growing sedimentary load forced the basins to subside further on, pressing the underlying crust into temperature regimes, where rock metamorphism led to volume reductions that maintained the tectonic subsidence [9] [10]. For the identical centers of both basins this must have happened twice, leading finally to a strengthened metamorphosed lower crust. The crustal rocks farther north remained at least less affected in Carboniferous times, staying available for intensive metamorphic processes that started with a thermal anomaly in Lower Permian (Rotliegend) times. In this region a new basin developed and the VDF had to subside accordingly to depths of more than $5 \mathrm{~km}$ 


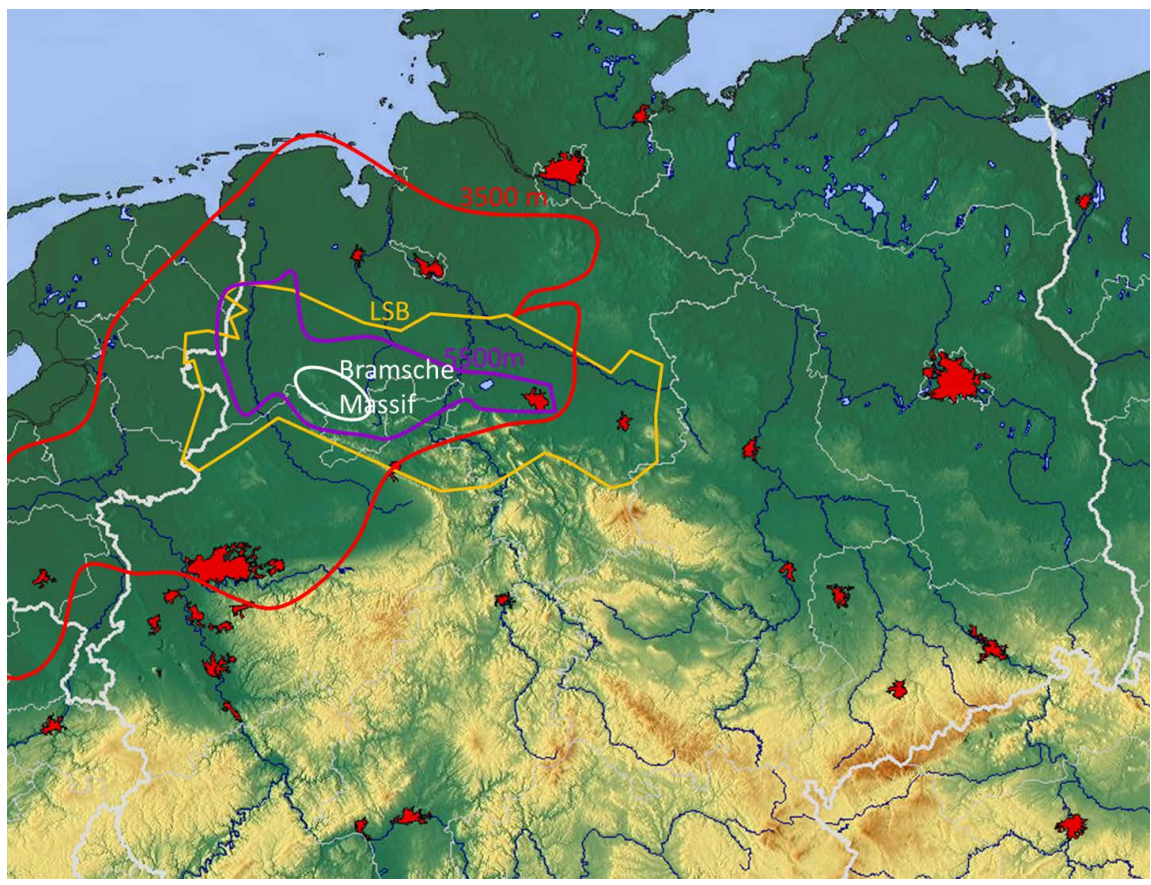

Figure 14. The $3500 \mathrm{~m}$ (red) and $5500 \mathrm{~m}$ (purple) isopachs of the Upper Carboniferous Variscan Foreland Basin, the sketched outline of the inverted (Mesozoic) Lower Saxony Basin (yellow) and the position of the Bramsche Massif (white).

today. Thick volcanics of Rotliegend age together with younger tectonic deformation of overlying strata are masking the exact position in the subsurface, making its seismic investigation a difficult undertaken.

The sedimentary fill of the Upper Carboniferous Foreland Basin with its coal seams, which are in total about $80-100 \mathrm{~m}$ thick, and the fill of the Lower Saxony Basin with Jurassic and Lower Cretaceous organic rich black shales relate both basins to the global distribution of hydrocarbon systems via their function as source rock depots. The ages of the source rocks are roughly 300 Million years and 150 Million years, respectively. A similar depositional periodicity has been observed in the same time spans for the global distribution of salt layers during dry climatic episodes. In Upper Jurassic times the Lower Saxony Basin became a depocenter for salt sediments, adding some sealing potential to its hydrocarbon system. As shown by [60] [61] [62] these sedimentary periodicities may have a galactic component, since the Phanerozoic climate appears significantly affected by the path of the solar system through the spiral arms of the Milky Way. Remarkably, the age distribution of White Dwarfs close to the solar system shows maxima 150 Million years apart with a time phase that fit to the other observations. White Dwarfs can be assumed as remnants of exploded stars (Supernovae). Therefore, the number of Supernovae per time unit with their ability to flood the Earth with energy may speculatively affect the geological evolution of the planet. Together with deep rooted causes inside crust, mantle and core this cosmic origin may contribute shaping the Earth as well.

The Lower Saxony Basin as information container for global processes runs 
oblique to the Variscan Deformation Front similar to its Upper Carboniferous precursor, similar to the oblique Lake of Constance Basin at the Alpine Front and similar to the oblique Vienna Basin at the Eastern Alps in Austria. Generally seen, orogenic processes may create minor oblique basins at their deformation fronts depending on available indenters below the forelands and strike slip abilities of their (deep rooted) fault systems. In this sense, a short discussion of the history of the Vienna Basin could be fruitful [63]. Similarities with the Lower Saxony Basin prior to the inversion are obvious, concerning the deposition of Jurassic source rocks and the importance of basin forming (indenter related) transform faults. However, significant differences between both basins still exist. Since the Vienna Basin developed on top of the folded and faulted Alpine body, the Variscan Deformation Belt, whatever the pattern might be, could be likewise present below the time delayed Lower Saxony Basin.

The very specific Upper Jurassic autochthonous source rocks (Figure 15) of the Vienna Basin represent a local facies anomaly on the European platform [64] [65]. The allochthonous gas bearing Triassic carbonate reservoir rocks [65] [66] of a specific nappe within the Northern Calcareous Alps (NCA) as well as a nappe of Upper Cretaceous to Palaeogene rocks with sealing capacity were stacked during the Alpine collision much further to the west and then due to the extrusion of the Eastern Alps (Figure 16) [67] [68] transpressively stretched and moved parallel to the Alpine axis into the present position just above the source rock spot. The source rock was subsequently buried into the HC-generation window by the internally structured allochthonous load ([69], adjusted). On top of the stacked and sheared Alpine nappes, the Vienna Basin evolved at this position with additional oil bearing Tertiary reservoirs as a piggy back basin along the Vienna Basin Transform Fault in Neogene times (Figure 17) contemporaneously with the development of the adjacent Pannonian Basin [70]. This transform fault dissects the Austrian Eastern Alps from the Slovakian Western Carpathians

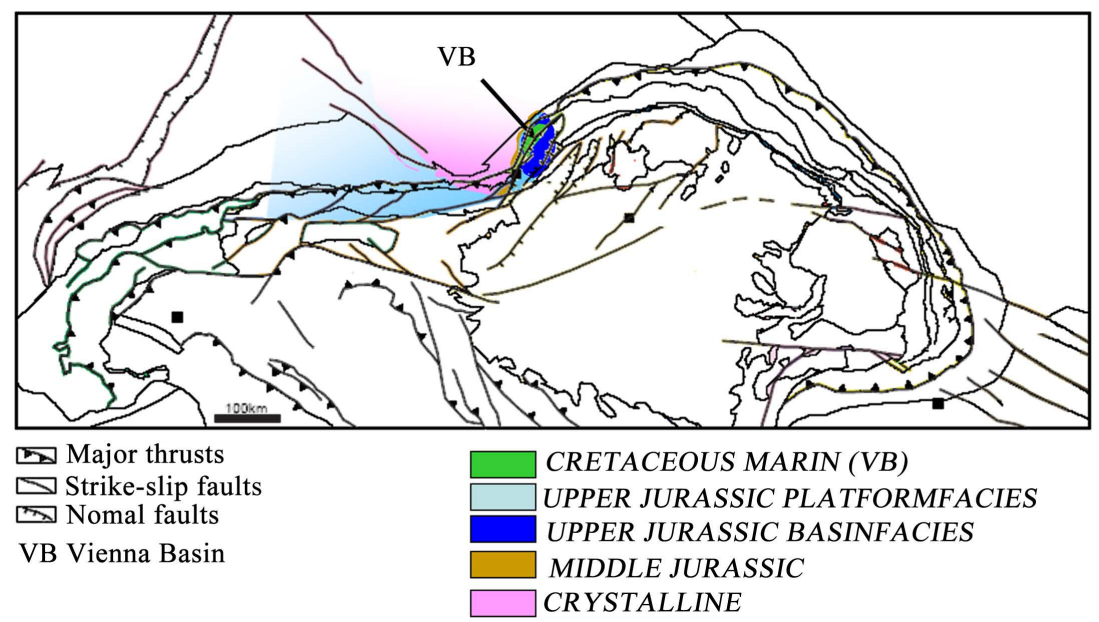

Figure 15. Autochthonous Upper Jurassic source rock spot (basinfacies) on the eastern side of a strong crystalline indenter and below the allochthones Vienna Basin (after [65], tectonic background map after [74]. 


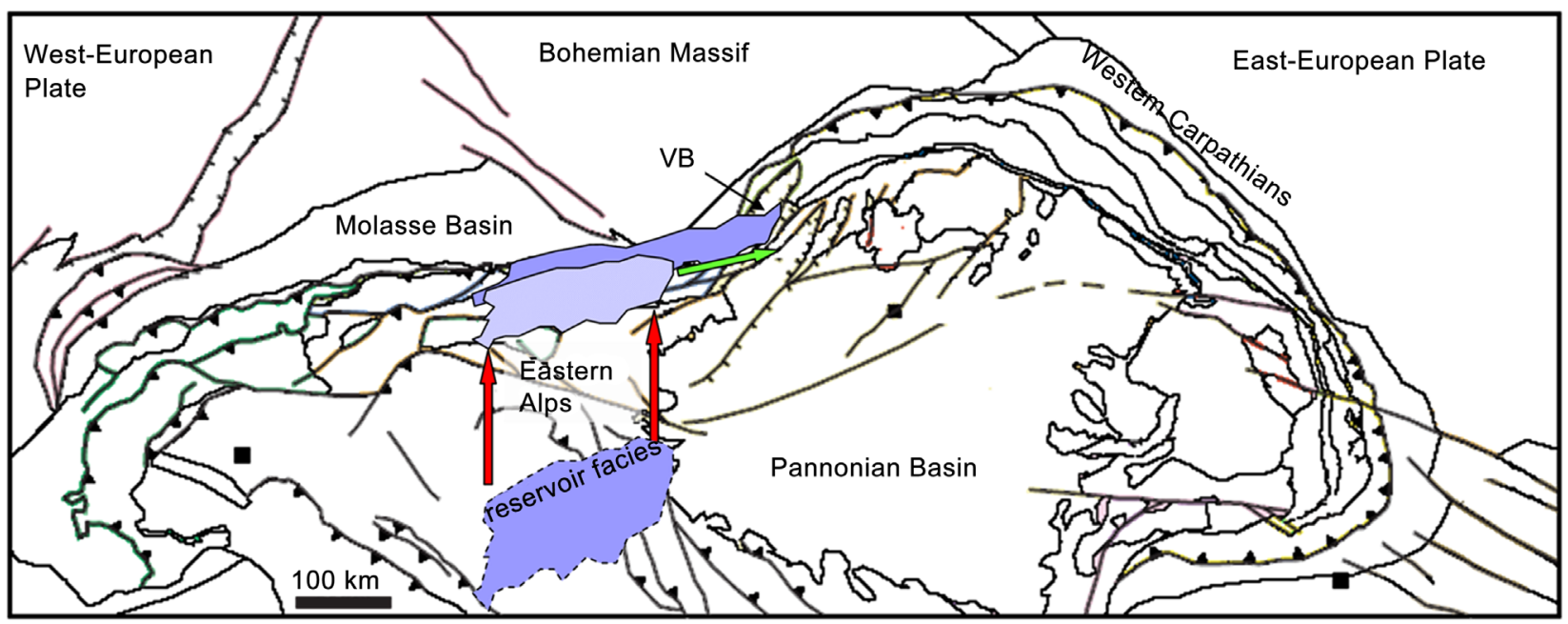

Major thrusts

Strike-slip faults

Allochthonous Northern Calcareous Alps today(reservoir nappe incl.)

$\rightarrow$ Nomal faults

Allochthonous Northern Calcareous pre-extrusion (reservoir nappe incl.)

VB Vienna Basin

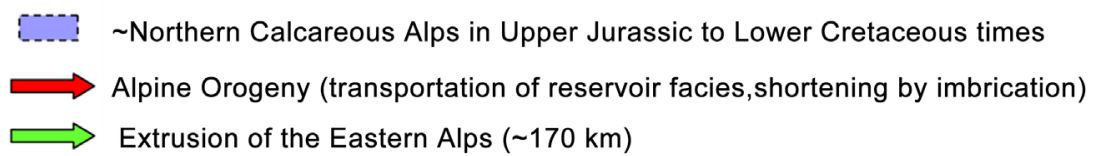

Figure 16. Geologic sketch of the Northern Calcareous Alps (reservoir nappe included) after lateral tectonic extrusion in Early to Middle Miocene times with tectonic background map after [74]. Palinspastic reconstruction for pre-extrusion times (Late Oligocene) (modified from [67]).

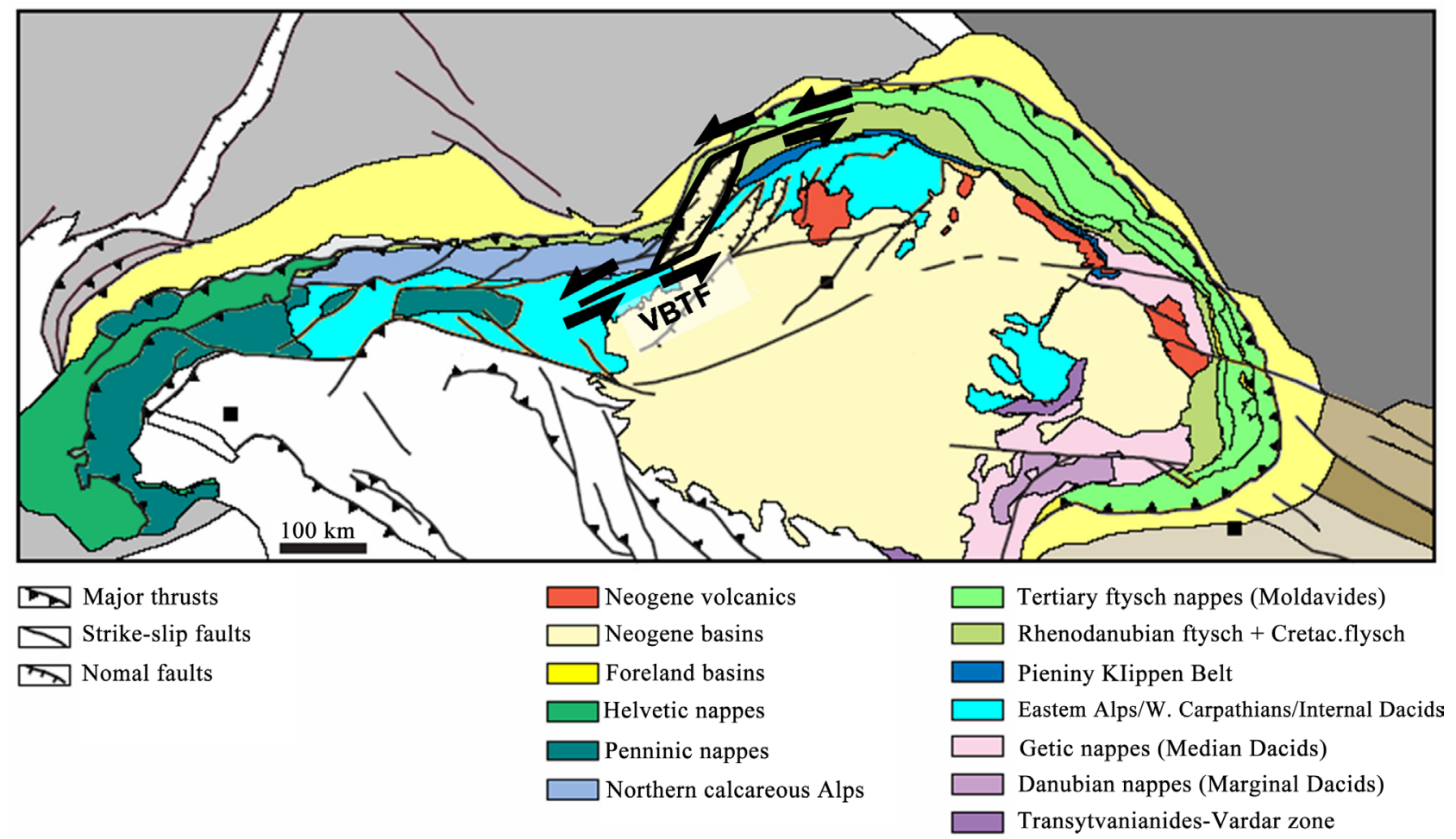

Figure 17. Forming of the Vienna Basin as a transtensional (pull-apart) Basin of Miocene age along the Vienna Basin Transform Fault (VBTF) on top of the Northern Calcareous Alps (after [71], tectonic background map after [74]. 
[71]. The tectonic thinning of the roughly $8 \mathrm{~km}$ thick NCA allochthonous nappe pile and the development of the overlying $5 \mathrm{~km}$ deep Vienna Basin [72] were spatially balanced and did not significantly affect the burial history of the underlying autochthonous source rocks (Figure 18).

Since the Variscan Deformation Front is bended around foreland indenters similar to the Alpine front in Eastern Austria, which is accompanied there by the extrusion related development of the Vienna Basin, an extrusion event of the Variscan Orogen could have been also a real case. It may have occurred in the Harz Mountains area collaterally with its different horizontal shortening and extraordinary vertical stack during the Variscan Orogeny (see further below). Those extrusions are generally not unique. A globally important horizontal extrusion has been recognized in Indochina. It is also a consequence of the evolution of an orogen, the Himalaya, accompanied by large lateral transform faults and by the development of hydrocarbon bearing extensional basins in Southeast Asia on a continental scale [73]. However, due to the close vicinity to Baltica only limited space was available for a significant extrusion along the Variscan front towards northeast and, instead, the Variscan Harz Mountains had to take up large amounts of the tectonic energy by growing up into the deep and height.

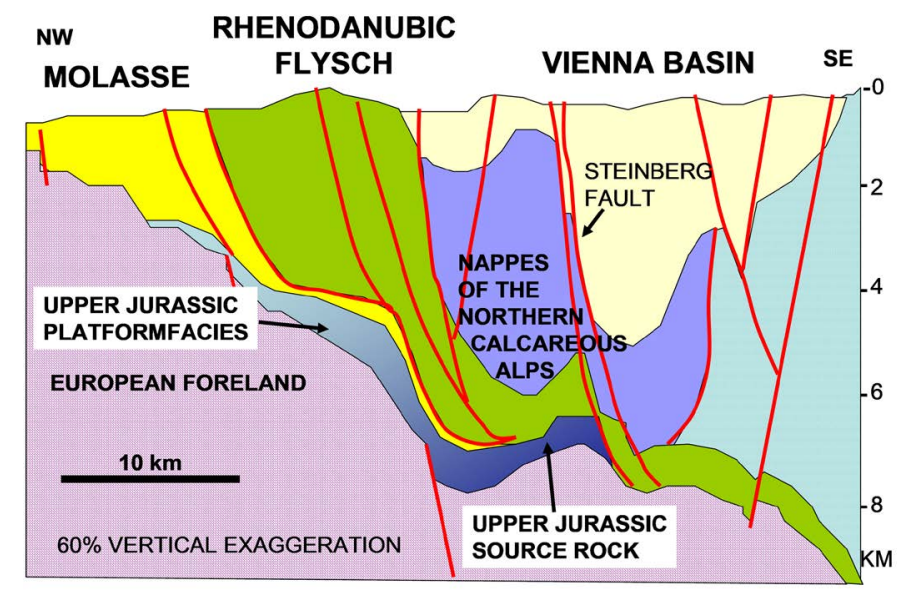

Figure 18. Cross-Section through the northern Vienna Basin after [75]. Note location of the major listric normal faults (Steinberg fault system, $5.6 \mathrm{~km}$ vertical throw), which root in the Alpine-Carpathian floor thrust. Location of major faults in the NW part of the basin results in an asymmetrical basin with strata tilted towards NW (see [72]).

\section{Bramsche Massif}

As already mentioned the level of knowledge about the VDF is minimized for the subsurface of the inverted Lower Saxony Basin (LSB) especially around the Bramsche anomaly. Reference [8] pass the problem by using LSBs southern border, the Osning fault, as continuation of the VDF towards the southeast, before it makes a general turn to the northeast again. Interestingly the LSB had a precursor in the Upper Carboniferous basin center [63]. Either the west-east orientation of the basin center developed contemporaneously during the subsidence of the SW-NE striking Upper Carboniferous foreland basin, or erosional processes 
dominated subsequently afterwards, effecting the (uplifted) southern and northern flanking areas more intensively. This observation is giving room for the assumption that within the Avalonian subsurface individual blocks reacted differently on increasing sedimentary loads and tectonic forces. Without having substantial data for the LSB, [14] suggest that the VDF is present below the western LSB in accordance with their findings further north.

The Bramsche anomaly, which is a pronounced gravimetric and magnetic high in the southwestern sector of the inverted Lower Saxony Basin, is characterized by high vitrinite reflectance values of surface rocks, and by the shallow depth (about $6 \mathrm{~km}$ ) of the seismic refraction horizon Ur [76] (Figure 19). In the past, these observations were interpreted by assuming a mafic intrusion of Upper Cretaceous age being the cause of all these different anomalies [76] [77] [78] [79], masking therefore geological and geophysical evidences of any kind of Variscan folding below.

Meanwhile, because some doubts about this interpretation could no longer be ignored [11], additional modern magnetotelluric (MT) measurements have been applied to get another independent view on the characteristics of the deep subsurface in that area (see [13] [37]. Seven further MT sites were selected on a SW-NE-oriented profile that traversed the centers of the gravimetric and magnetic anomalies and the coalification maximum as closely as possible (Figure 20 ). Within the northeastern part of the MT profile, a significant good conductor can be observed at a depth of about $6 \mathrm{~km}$ (Figure 21). The low resistivity layer diminishes rapidly towards southwest, where the depth range between 6

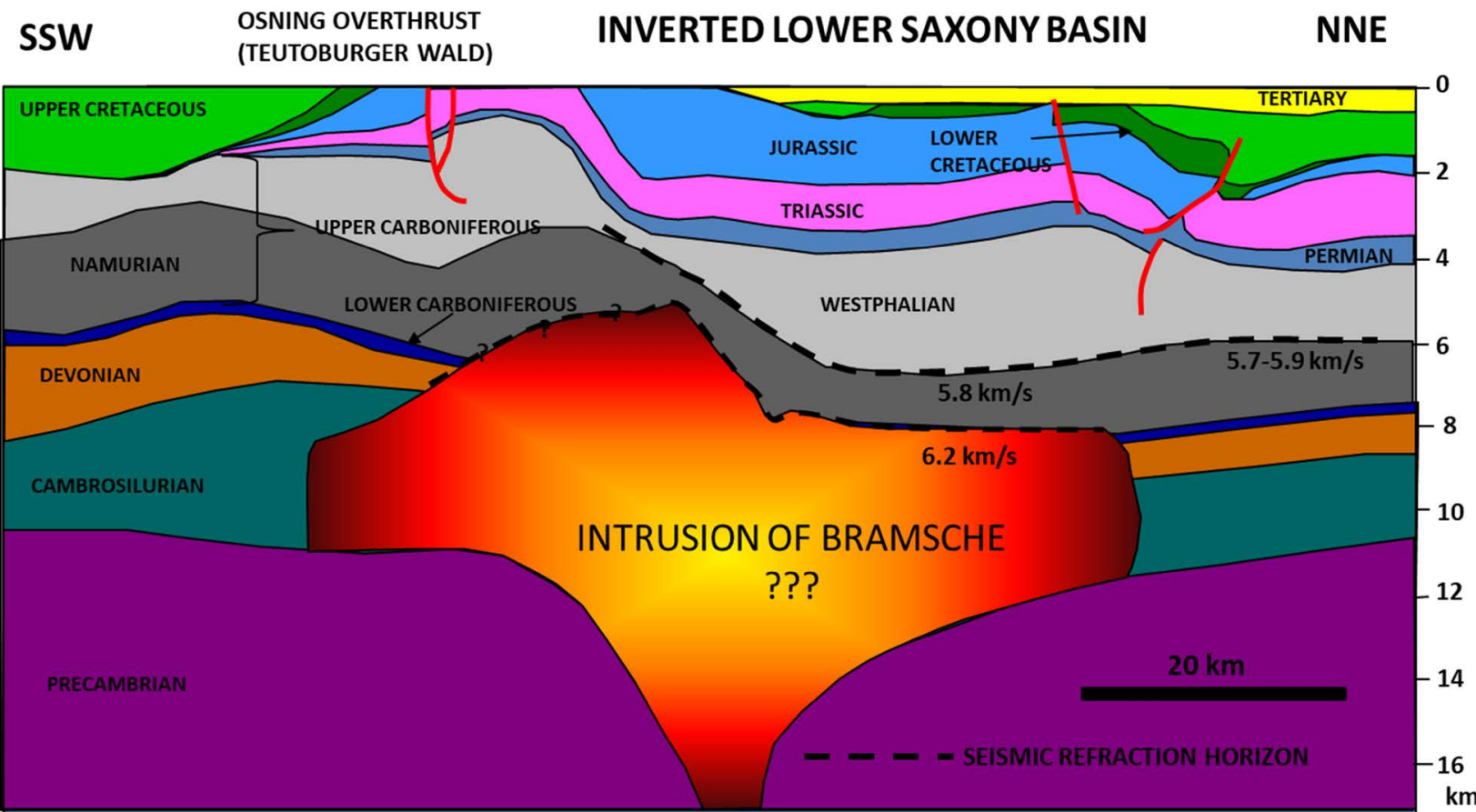

Figure 19. Cross-Section of the inverted Lower Saxony Basin and the intrusion of Bramsche, after [87], Interpretation of refraction seismic line [76]. 


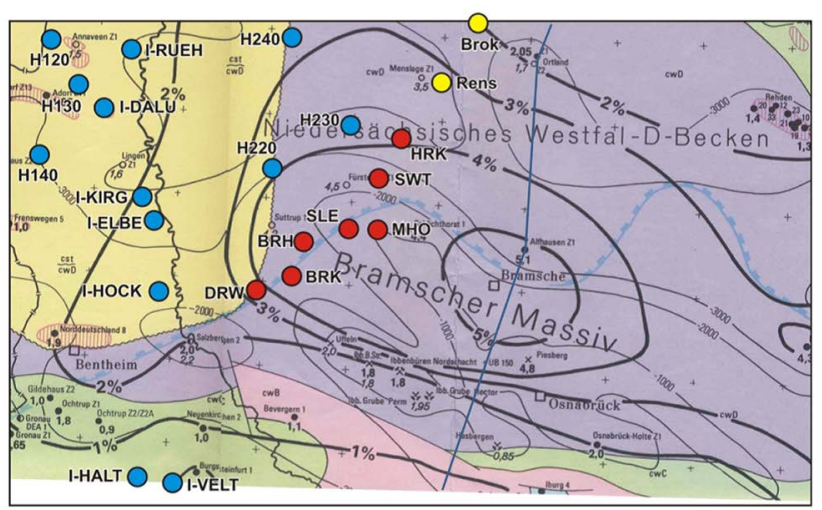

MT-sites 1998 Cross Section

MT-sites 2002 (MT-sites Bramsche massif)

MT-sites 2003

(a)

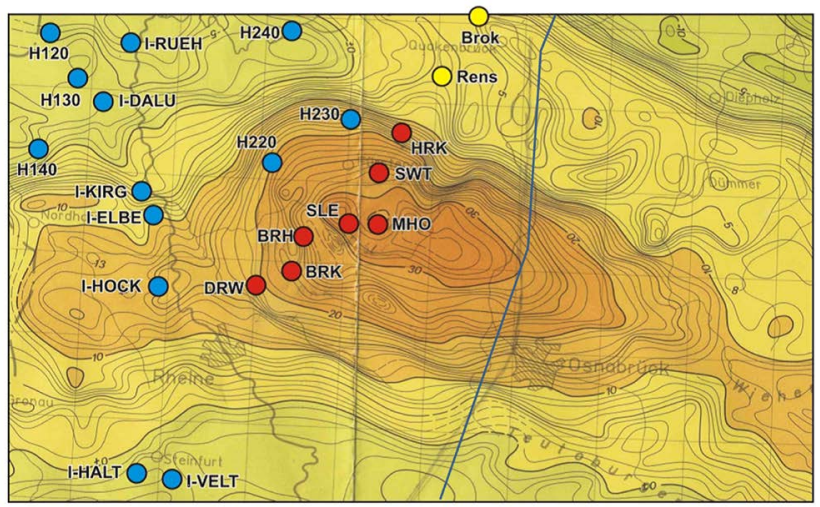

MT-sites 1998

Cross Section

MT-sites 2002 (MT-sites Bramsche massif)

MT-sites 2003

(b)

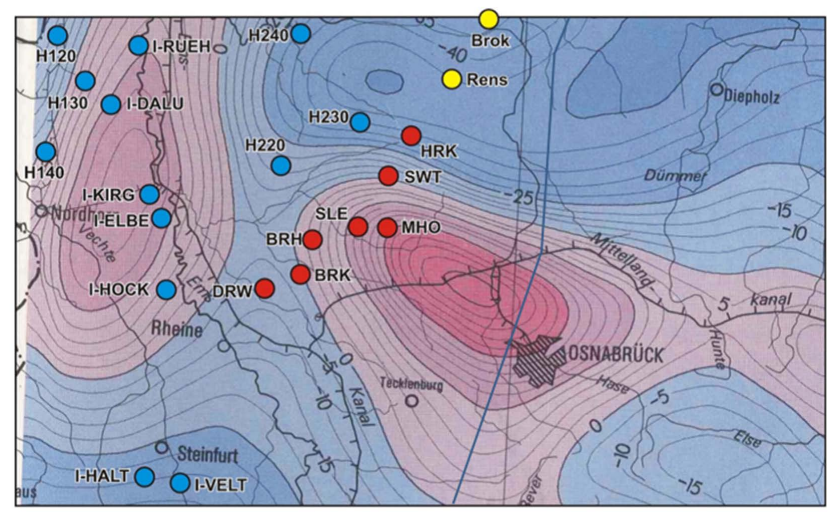

MT-sites 1998

MT-sites 2002 (MT-sites Bramsche massif)

MT-sites 2003

$$
\text { Cross Section }
$$

(c)

Figure 20. Coalification-after [78] (a), gravimetric-after [88] (b) und magnetic anomalies of Bramsche-after [89] (c) with positions of MT-sites in the area of Bramsche (in red) and the position of the cross section of Figure 19. 


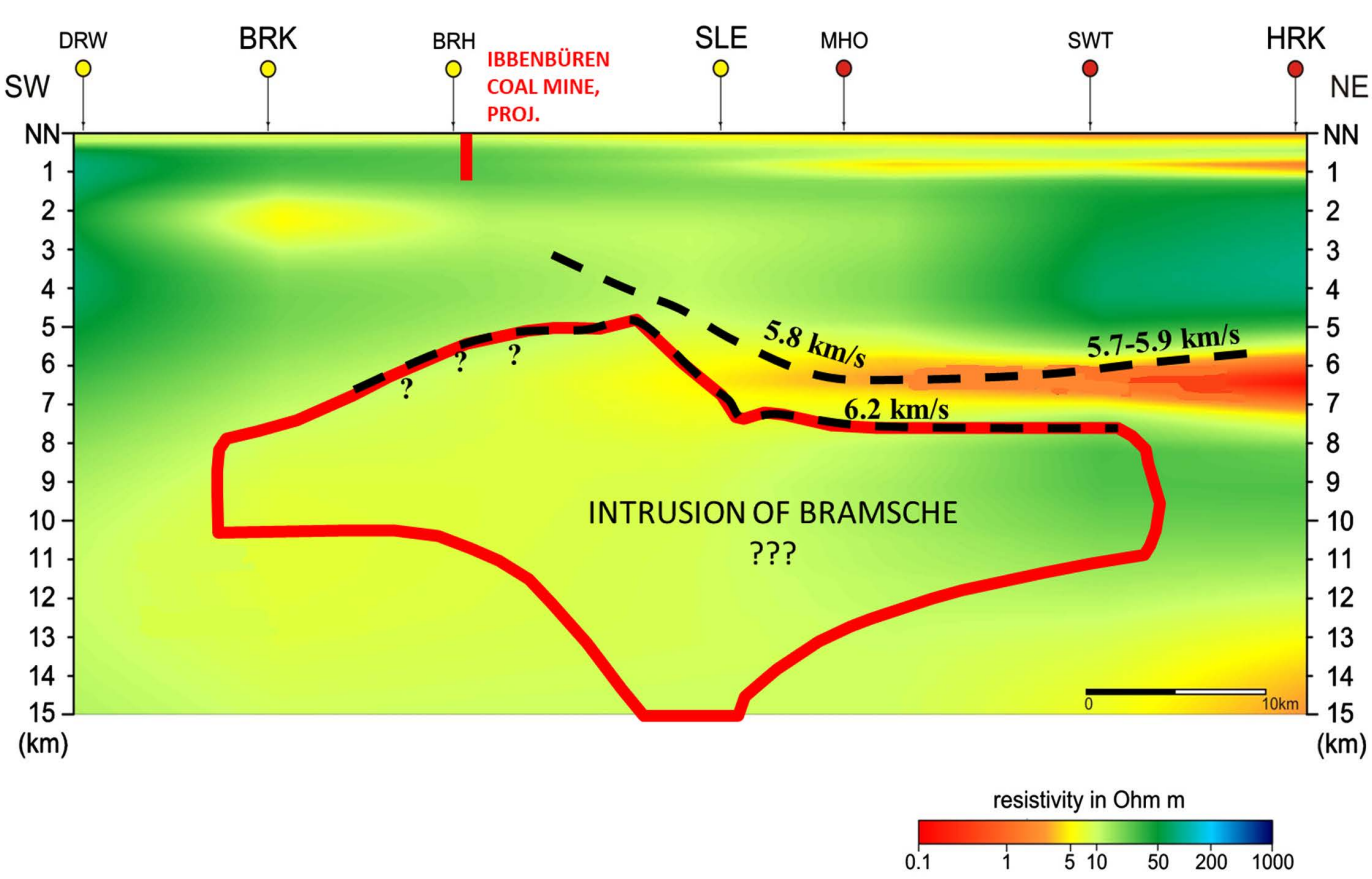

Figure 21. Interpretation of a refraction seismic line [76] merged with the nearby resistivity section of the Bramsche profile [12].

and $20 \mathrm{~km}$ is characterized by a moderate resistivity of about $5-10 \mathrm{Ohm} \cdot \mathrm{m}$. The good conductor of the northeastern sector can be correlated with the good conductor of the Emsland-East Friesland profile. Highly coalified, anthracitic Westphalian coals (mined in the Ibbenbüren area) may cause these very low resistivities. The zone below the good conductor is characterized by a higher resistivity of about $50 \mathrm{Ohm} \cdot \mathrm{m}$, which can be related to the presence of Lower Carboniferous and Devonian carbonates that overlie Cambro-Silurian and pre-Cambrian rocks.

The interpretation of the southwestern sector of the MT profile is more problematic. The absence of a good conductor at a depth of $6 \mathrm{~km}$ could be an indication that the coals have not been sufficiently coalified to be good conductors. However, an inversion of the Lower Saxony Basin of up to $6 \mathrm{~km}$ can be assumed in the area of Bramsche [11] [12] [80] [81] [82] [83]. Due to the high vitrinite reflectance values at the surface pointing to an even higher coalification at greater depth, a good conductor should be present.

In addition, a zone with a high resistivity of $200-1000 \mathrm{Ohm} \cdot \mathrm{m}$ and a poor conductivity down to depths much greater than $10 \mathrm{~km}$, representing the postulated intrusive body with its genuine high resistivity, was expected beneath the identified moderate low resistivity zone. Therefore, at least at the location of the MT profile, the presence of an intrusion appears to be doubtful. This is also supported through merging the interpretation of a nearby refraction seismic line with the presented MT-data (Figure 14). The deeper refraction horizon with a velocity of about $6.2 \mathrm{~km} / \mathrm{s}$ may represent the Lower Carboniferous and Devonian carbonates lying concordantly below the conductive Westphalian coals and possi- 
ble Namurian black shales in the northeastern portion of the profile. Should the Variscan Deformation Front have passed the location of the cross-section (Figure 19 and Figure 20), the refractor would possibly represent the base of slightly folded and faulted Upper Carboniferous strata. The anthracitic coals of Ibbenbueren, which were mined at a depth of about $1500 \mathrm{~m}$ (about the BAH location) until 2018, do not have a magnetotelluric signal. This may be caused by tectonic faults, which eliminate the good lateral conductivity of the uplifted Westphalian coal layers in shallow depths. Moreover, there are no indications reported from mining that those tectonic faults have been created by the migrating Variscan Deformation Front.

However, the strong mineralization that has been interpreted to be related to the "Bramsche intrusive" [84] may have hampered the detection of the high resistivity zone and may cause the thick, moderate conductive layer in the southwestern sector of the profile. By ignoring the presence of a shallow intrusion, [39] estimated a density of up to $3.3 \mathrm{gr} / \mathrm{cm}^{3}$ for a body at depths of more than 12 $\mathrm{km}$ at the location of the Bramsche anomaly. This interpretation requires a significant presence of mafic granulites or eclogites within the lower and middle crust, but there appeared no compatible tectonic model available at that time. Metamorphism to eclogite is only possible under a very high-pressure regime that should be about twice as high as for the current conditions. But exactly this could have occurred during the inversion of the Lower Saxony Basin. According to [85], twice the lithostatic pressure can be achieved in regions undergoing horizontal shortening, and during the inversion of the Lower Saxony Basin, pressures may have developed that would support the metamorphism of crustal rocks into eclogites. The increase of rock density will be accompanied by a loss of fluids out of the metamorphosed rocks. These fluids may carry ions to shallower depths, and they could be the source for ore mineralization in the overlaying strata. Ore mineralization within the Lower Saxony Basin (LSB) has been described in detail by [84]. However, [86] updated and adjusted the intrusion model to incorporate recent data, and also modeled pre-Zechstein structures using different scenarios. Based on currently available seismic and structural models, as well as borehole density measurements, they postulate that the positive Bouguer anomaly cannot be modeled without a high-density (about $3 \mathrm{gr} / \mathrm{cm}^{3}$ ), "intrusive-like" body at depth. Alternatively [12] proposed an eclogitic body at a depth deeper than $12 \mathrm{~km}$ with a very high rock density of $3.3-3.4 \mathrm{gr} / \mathrm{cm}^{3}$, situated above the magnetically important Curie depth of about $25 \mathrm{~km}$. This body of metamorphosed crustal rocks developed during the inversion process in Upper Cretaceous time and later and would fit to the assumptions of [39].

\section{Harz Mountains/Moho}

A Central European cutout of the Moho depth map after [90] (Figure 22), exclusively based on published regional Moho depth maps, shows values between 30 and $32 \mathrm{~km}$ without any distinguished anomaly for the Harz Mountain area (red circle). However, local reflection and refraction seismic lines (Figure 23), 


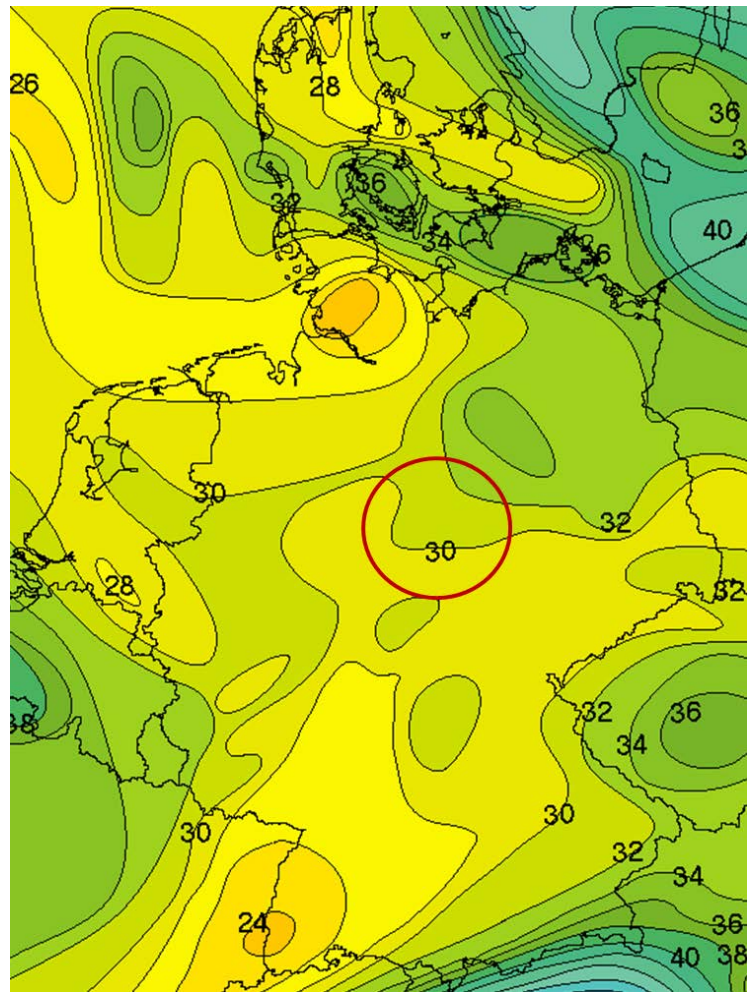

Figure 22. Cutout of the Central European Moho depth map (km) (crustal thickness of Western and Central Europe) after [90], Harz Mountains region: red circle.

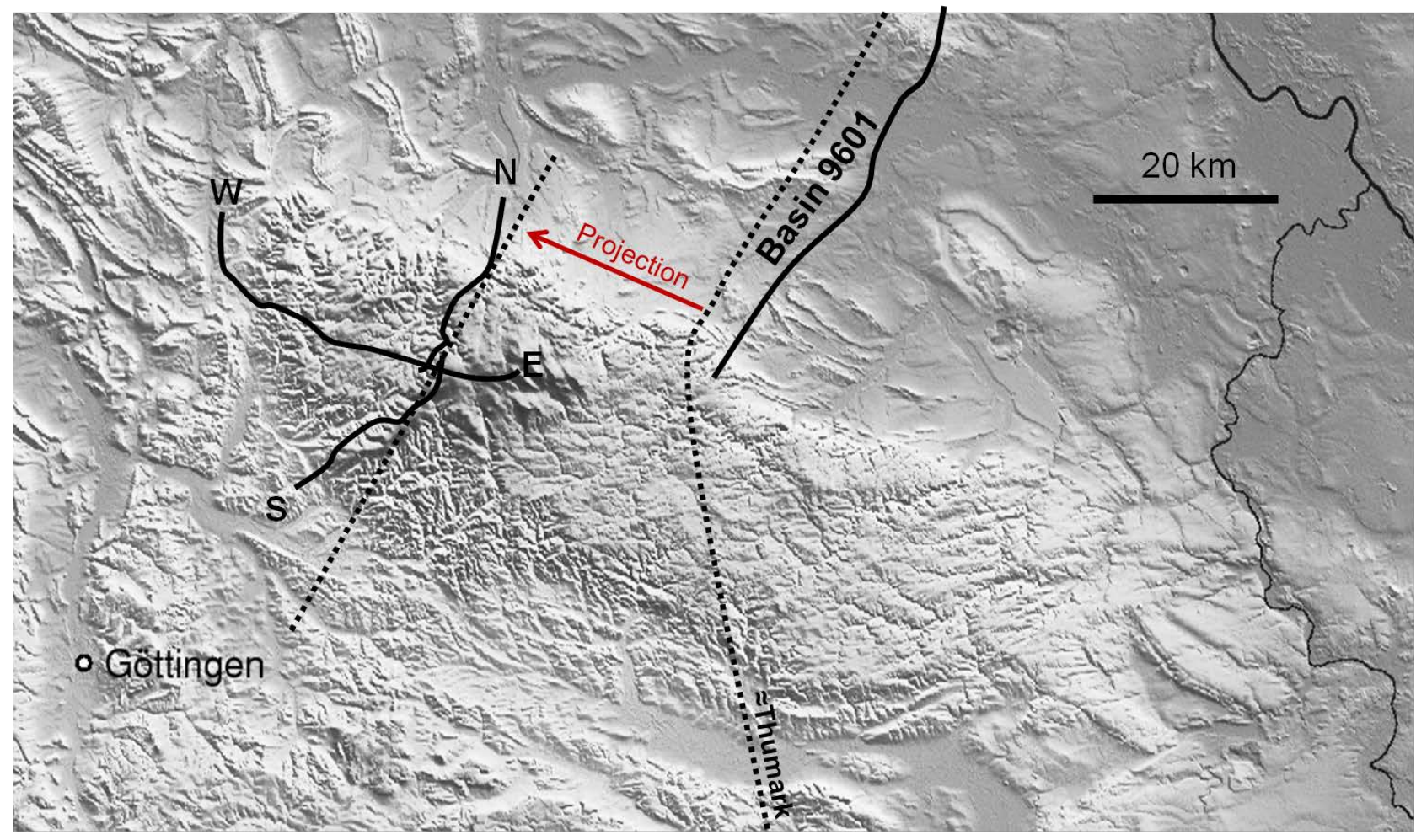

Reflection seismic traverses - NS: 8305, 8306, 8401 + 8402, EW 8407, Basin 9601

Refraction seismic traverse

Figure 23. Location map of reflection seismic lines (continuous lines) in the Harz Mountains and of refraction seismic traverses (dotted lines) after [15], modified. 
approaching or crossing the Harz Mountains, deliver conflicting results. According to the interpretation of the Basin 9601 reflection seismic line [91], the Moho depth increases from about $28 \mathrm{~km}$ at $50 \mathrm{~km}$ north of the Harz Mountains to about $37 \mathrm{~km}$ just at its northern border. Based on the reflection seismic data processing of an industrial refraction seismic traverse [16] crossing entirely the Harz Mountains from NNE to SSW, the Moho depth remains constant at about $37 \mathrm{~km}$ below this area (Figure 24). The refraction seismic Thumark traverse, crossing the Harz Mountains roughly $30 \mathrm{~km}$ to the east and interpreted by [92] in a complex manner including gravimetric, geomagnetic, geothermic and magnetotelluric data as well as petrophysical parameter relationships, shows just the opposite. North of the Harz the depth of the Moho reaches from $33 \mathrm{~km}$ at its northern border to a depth of about $34 \mathrm{~km}$ farther $50 \mathrm{~km}$ northwards. Below the Harz the Moho experiences an uplift of about $4 \mathrm{~km}$ at its northern border to a depth of about $29 \mathrm{~km}$ and dips down to about $31 \mathrm{~km}$ at its southern edge. These conflicting results about the true depth of the crust-mantle boundary (Moho) of the Harz Mountains, probably supported by a poorly reflecting scattering surface at the refractor depth, may be discussed in view of the study by [93] and [94].

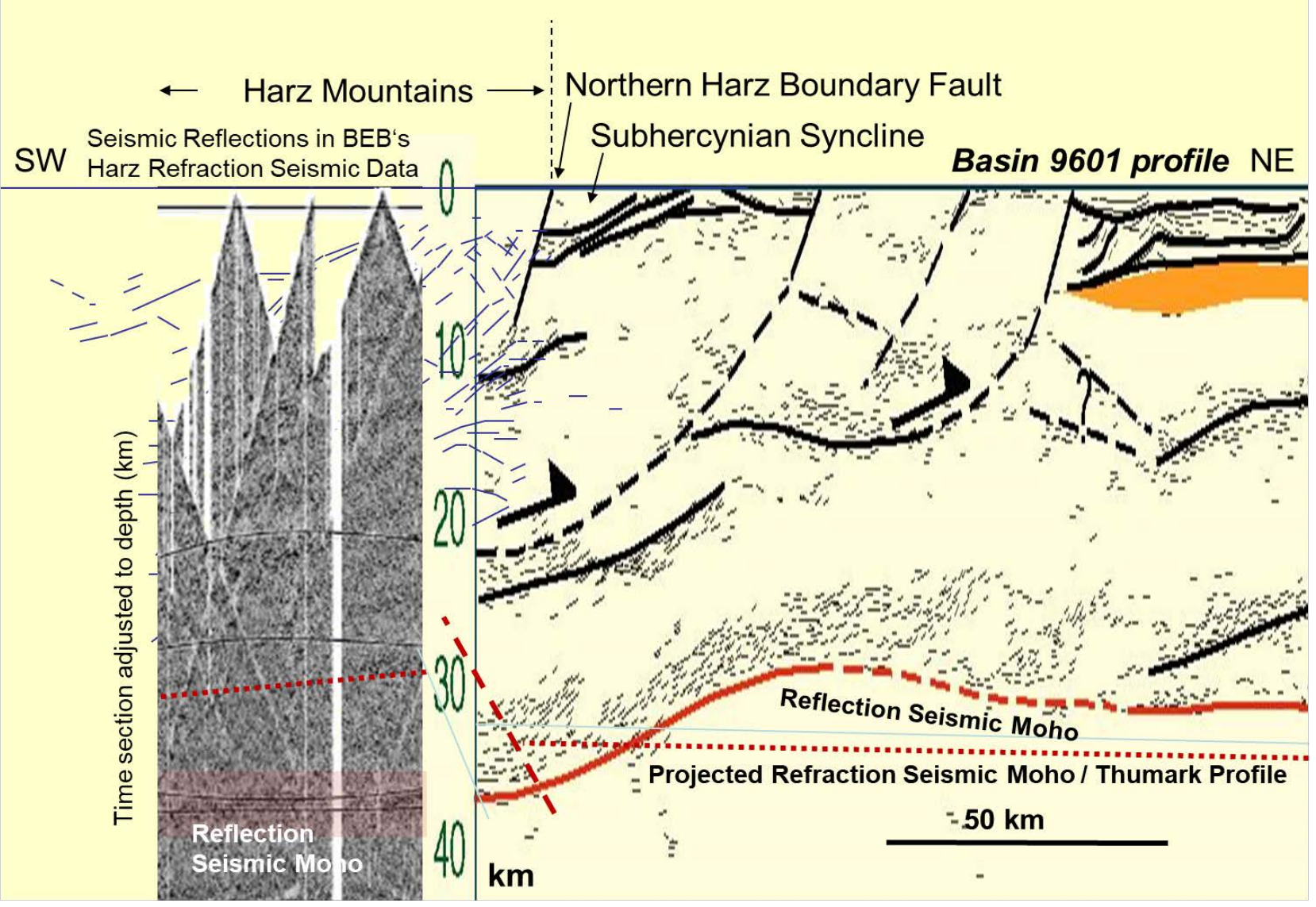

Figure 24. Combination of the line drawing of the Basin 9601 profile (Dekorp Program, [91]) with the re-processed seismic reflections of BEB's industrial Harz refraction seismic line, and with the interpretation of the Thumark refraction seismic line $30 \mathrm{~km}$ farther east [92], showing different Moho solutions below the Harz Mountains and its northern foreland. Modified after [15]. 
They used a compilation of experimentally determined P-wave velocities and densities for mafic granulites, gabbroic rocks, eclogites and peridotites to evaluate key physical properties of lower crustal mafic rocks during crustal thickening caused by continent-continent collision. They demonstrated that the position of the seismic Moho (defined as a first-order velocity discontinuity) and the petrological Moho (defined as the boundary between non-peridotitic crustal rocks and olivine-dominated rocks) are not identical for the case that mafic rocks are transformed into eclogites at the base of orogenically thickened crust. P-wave velocities of eclogites largely overlap with those of peridotites, although their densities are significantly higher than common upper mantle rocks. As a consequence, refraction seismic field studies may not detect eclogites as crustal rocks. This means that the seismic Moho detected by refraction seismic field studies appears at the upper boundary between eclogites and overlying crustal units. Since eclogites generally have higher densities than peridotites, they might be recycled into the deeper lithosphere. The interpretation of [93] and [94] is supported by the study of [92]. They assume an eclogitic low velocity mantle around the eastern Harz Mountains as an alternative to a peridotitic mantle. As the Harz Mountains have been uplifted since Upper Cretaceous times for some kilometers [95] [96], roughly contemporaneously with the inversion of the Lower Saxony Basin und the development of the Bramsche Massif therein, the pre-Upper Cretaceous "Moho" depth was certainly uplift corrected much larger. This should have supported the metamorphism of lower crustal rocks of the mountain root into garnet granulite to eclogite-facies assemblages. Based on well data (Flick 1986), the discussed Northern Harz Boundary Fault may have experienced a vertical throw of $6 \mathrm{~km}$. Reference [96] assumes a magnitude of vertical displacement of at least $7 \mathrm{~km}$, perhaps even $10 \mathrm{~km}$. The metamorphism may be currently suspended due to uplift enforced decline of pressure and temperature accompanied by limited additional stress through minor horizontal shortening. Independent from the true Moho depths, the observation remains that the refraction seismic velocity of the Harz area Moho has anomalous low values [15], pointing to an uncompleted metamorphism of the root.

Conclusively, the former root of the Rhenohercynian-Saxothuringian zones around the Harz Mountains was probably $5 \mathrm{~km}$ thicker than elsewhere else in the Rhenish Massif. This larger root certainly represented mountain ranges within the Variscan Orogen that were the highest of central Europe in late Paleozoic times, characterizing an outstanding high altitude topographic feature. Assuming a simple Airy isostasy, a $25 \mathrm{~km}$ thick mountain root as an assemblage of very different rock types might have carried a mountain range with an average elevation of 2.75 to $5.5 \mathrm{~km}$, depending on the involved rock densities (e.g. manthe $\sim 3.3 \mathrm{gr} / \mathrm{cm}^{3}$, root $\sim 2.7-3.0 \mathrm{gr} / \mathrm{cm}^{3}$, orogen $\sim 2.7 \mathrm{gr} / \mathrm{cm}^{3}$ ). The presence of the Permo-Carboniferous Halle-Saale-Trough, situated roughly southeast of the Harz Mountains and partly overlain by the Permo-Triassic Thuringian Basin [4] [97] [98], can be used as a clue for the estimation of the peak elevation of the Varis- 
can Orogen at this location. The trough contains limnic coal layers and conglomerates of Westphalian to Stephanian/Lower Rotliegend age (see [98]), pointing to swamps with Permo-Carboniferous rainforests and to an adjacent rough topography. The maximum elevation, at which rainforests can flourish today, is about $2 \mathrm{~km}$, which will be taken here as a rough estimate for the Permo-Carboniferous time, too. Taking into account the average elevation of the Variscan Orogen at this place, the mountain ranges (including volcanic peaks) adjacent to the Halle-Saale-Trough might have been 3.5 to $9 \mathrm{~km}$ high. Still for the average case of $6.25 \mathrm{~km}$, many peaks might have been permanently covered with ice and snow (approximately above $5 \mathrm{~km}$ ) at that time. High mountain ranges were certainly meteorological and drainage divides, guarantying rainfall in Permo-Carboniferous trade wind latitudes predominantly in mountain valleys located within the eastside of the Variscan Orogen. On the westside of the Variscan Mountains, rainfall was an exception and a dry arid climate prevailed, leading to the development of salt flat rich deserts in the developing North German Rotliegend basin as recorded. The Permo-Carboniferous high altitudes of the Harz Mountains, today still retained in its unfinished root, are an indication for a specific local orogeny that the vertical stacking of tectonic nappes was less energy consuming than overcoming the resistance of pushing the Variscan deformation horizontally much further on towards the Bramsche region. For these circumstances some kind of LSB-related indenter in the foreland-at least bounded by the Osning and Cloppenburg faults and their extensions-should be required.

\section{Discussion}

A review and analysis of the presented and cited observations lead to following conclusions included in one map (Figure 25):

1) In Northrhine-Westfalia southwest of the Lower Saxony Basin bordering southern Osning fault the Variscan deformed anticlines (folds) of the foreland are significantly elongated with a low wavelength fold pattern. Farther to the west and south of the pre-Variscan Brabant Massif in Belgium and extending into the Aachen area, the Variscan Deformation Front is comparable narrow and thrust dominated.

2) Since no similar pattern could be recognized northeast of the Osning fault, [8] proposed a trend of the Variscan Deformation Front (VDF) as shown in red. 3) North of the Lower Saxony Basin, which southwestern section is roughly bordered by the northern Cloppenburg fault, Variscan deformed anticlines (folds) are arranged within a large wavelength fold pattern, modified by NW-SE (Hercynian) running (strike-slip) faults [14]. Therefore, the structural trends of the Carboniferous in Northrhine-Westfalia find their extension towards the so-called Pompeckij Block in Lower Saxony north of the inverted Lower Saxony Basin (LSB). This poses the question whether the Carboniferous beneath the LSB is folded as well. According to their interpretation [14] shifted the location of the VDF farther to the west (shown in dark yellow) 


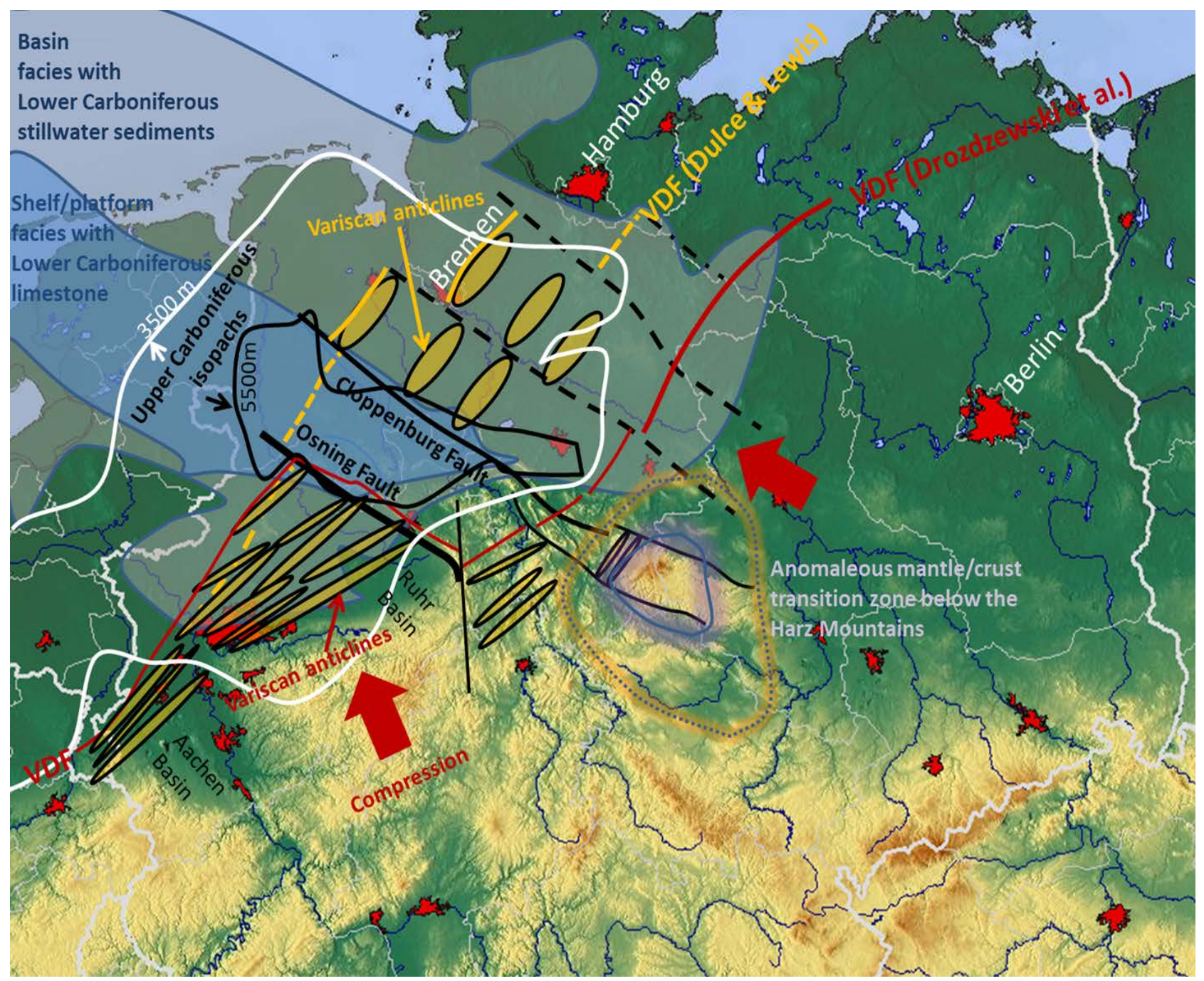

Figure 25. Compilation of observations related to the definition of the Variscan Deformation Front (VDF): Lower Carboniferous facies distribution, selected Upper Carboniferous Basin isopachs (3500 and $5500 \mathrm{~m}$ ), Variscan anticlines and faults after [8] and [14], and Harz Mountains anomalies (low Moho velocity: outer dotted line, deep reflection Moho: inner full line).

4) In the area of the inverted Lower Saxony Basin (southwestern sector) that is generally located between the Osning and Cloppenburg faults no fold pattern has been recognized so far perhaps due to poor data. Some solutions are available now to fill this gap:

- No fold pattern exists at all [8]

- A fold pattern is present and may have a form either similar to that of the north [14] or to that of the south [8] or has a shape with another independent wavelength and a different extension

- The southern and northern fold patterns interfere to a complex wavelength modulated pattern.

- However, similar to the North Alpine Foreland Basin (Molasse Basin) structural styles within the Variscan Foreland may have changed significantly on a short distance. 
5) The western part of the inverted Lower Saxony Basin and the center (5500 $\mathrm{m}$ isopach) of the generally striking (SW-NE) Variscan Upper Carboniferous basin (3500 $\mathrm{m}$ isopach) coincide significantly in their common location and their general WE-extension, leading to the assumption that the development of both basins is similarly controlled by attributes of the underlying Avalonian crust system, possibly due to rock properties with a different (faster) metamorphism rate other than the ones of the northern and southern blocks. These different metamorphism rates with their rock volume reduction potential may affect timewise the subsidence rates of adjacent blocks considerably.

7) Magnetotelluric data combined with geological and other geophysical evidences suggest that during the Lower Carboniferous the deposition of carbonates prevailed between the Osning and the Cloppenburg faults whereas south and north of the LSB the deposition of stillwater shales dominated. This is additionally pointing to a basement controlled sedimentation regarding the immediate center of the Upper Carboniferous basin (5500 $\mathrm{m}$ isopach) and the Lower Saxony Basin.

8) The ductile stillwater shales may have influenced the development of folds and thrusts during the Variscan Orogeny differently compared to the more rigid carbonates and their substratum, which may feedback with the Rhenohercynian belt in an alternative way.

9) At least four different styles of the Variscan Deformation Front have been identified in Northwest Germany so far. Further styles may be present towards Northeast Germany as the VDF approaches Baltica.

10) Further important observations are the mantle/crust transition zone anomalies of the Variscan Harz Mountains. Anomalous low Moho velocities have been identified in an area surrounding the Harz (outer dotted line) as well as an anomalous deep reflection seismic Moho of smaller extent just below the Harz (inner full line) and a seismic refractor, regarded as caused by the Moho boundary, too, some kilometers shallower. These seismic events may represent bottom and top of the mantle/crust transition zone identical with the remaining root of the Harz Mountains. That the refractor horizon does not act as a recognizable reflection boundary in the standard seismic processing procedure may be caused by its "frozen" incoherent seismic scattering attitude due to small scale horizontal impedance contrasts, enforced by a kind of fingering of the thermally driven metamorphism front inside the root of the Harz Mountains.

11) The tectonic nappes of the Harz Mountains were vertically stacked during the Variscan Orogeny probably to an anomalous high altitude by horizontal shortening and a very deep root, pointing to a resisting crustal indenter in the foreland. This towards The Netherlands extending indenter may have acted also as pushback to the Variscan Deformation of the foreland between the somehow masked eastern extensions of the Osning and Cloppenburg faults yielding to a different, still unsolved tectonic answer compared to the conditions south and north of the LSB. A horizontal extrusion-like squeezing similar to the situation 
of the Northern Calcareous Alps appears possible, however, of low amplitude.

\section{Conclusion}

Biogeographical data, paleomagnetic restrictions, geological indications, volcanic pyroclastic events, magnetotelluric recordings, reflection and refraction seismic, gravimetric, magnetic and thermal interpretations, geochemical investigations and petrological relationships became the base for a reinterpretation of the Variscan Deformation Front in Northwest Germany. Starting with the "Avalonian Terrane Assemblage" and its subdivision into different sectors of a horst and graben system, in Late Devonian to Early Carboniferous times sedimentation took place mainly of marine carbonates on the horsts and Stillwater shales in the grabens, respectively. During the Late Carboniferous Variscan Orogeny, this terrain became affected by the colliding Rhenohercynian belt in diverse ways, depending on the properties of the underlying sedimentary strata and deeper crustal rocks. Folding or thrusting with different anticlinal patterns occurred in the foreland and the dominant carbonate covered horst in-between reacted assumingly as a resisting indenter. This horst was the location of the Late Carboniferous basin center and similarly of the inverted Mesozoic Lower Saxony Basin with the so-called Bramsche Massif therein. It probably caused the Variscan Harz Mountains to get stacked up to very high altitudes and the root into large depths. This root is still an uncompleted metamorphosed crust/mantle transition zone with a deep reflection seismic/petrological Moho and a shallower refraction seismic velocity Moho. The alternative, partly unsolved location of the Variscan Deformation Front may represent the new findings, maintained by comparison with features of the northern Alpine deformation belt.

\section{Acknowledgements}

The author would like to thank an unknown number of anonymous reviewers for their support, Norbert Hoffmann, Stahnsdorf for his extraordinary innovative geological and magnetotelluric groundwork and for his permission to use his figures, Heinrich Brasse, Berlin for his professional geophysical advice, both for their respectful cooperation during the preparation of this publication, Gerhard Bachmann, Halle for his substantial preview of an early version of the manuscript and Peer Hoth, Potsdam for his collegial encouragement. He thanks BEB/ExxonMobil Germany for the release of their refraction seismic traverse data crossing the Harz Mountains and the Institute of Geophysics of the University of Hamburg for supervising the master thesis on working with seismic reflections contained within those refraction seismic data. Through assisting Norbert Hoffmann further technical help was provided by Gerhard Kapinos. The topographic background map of figures 14 and 25 is taken from the Maps-for-free website. To appreciate the authors of the reference list and their work appropriately and to keep the information loss as low as possible, some phrases and figures of few cited articles-including the own ones-have been changed only 
slightly to support logic and conclusion of this paper properly. For an intensive examination of some discussed issues, the reader is referred to the cited original work.

\section{Conflicts of Interest}

The author declares no conflicts of interest regarding the publication of this paper.

\section{References}

[1] Pharaoh, T.C. (1999) Palaeozoic Terranes and Their Lithospheric Boundaries within the Trans-European Suture Zone, TESZ: A Review. Tectonophysics, 314, 17-41. https://doi.org/10.1016/S0040-1951(99)00235-8

[2] Ziegler, P.A. (1988) Evolution of the Arctic-North Atlantic and the Western Tethys. AAPG Memoir 43, American Assoc. Petroleum Geol., Tulsa, 1-197.

[3] Ziegler, P.A. (1989) Evolution of Laurussia. Kluwer Academic Publishers, Dordrecht. https://doi.org/10.1007/978-94-009-0469-9

[4] Ziegler, P.A. (1990) Geological Atlas of Western and Central Europe. Geological Society Publishing House, den Haag.

[5] Franke, W., Robin, L., Cocks, M. and Torsvik, T.H. (2017) The Palaeozoic Variscan Oceans Revisited. Gondwana Research, 48, 257-284. https://doi.org/10.1016/j.gr.2017.03.005

[6] Winchester, J.A., Pharaoh, T.C. and Verniers, J. (2002) Palaeozoic Amalgamation of Central Europe: An Introduction and Synthesis of New Results from Recent Geological and Geophysical Investigations. Geological Society London Special Publications, 201, 1-18. https://doi.org/10.1144/GSL.SP.2002.201.01.01

[7] McKerrow, W.S., Mac Niocaill, C., Ahlberg, P.E., Clayton, G., Cleal, C.J. and Eagar, R.M.C. (2000) The Late Palaeozoic Relations between Gondwana and Laurussia, Geological Society London Special Publications, 179, 9-20. https://doi.org/10.1144/GSL.SP.2000.179.01.03

[8] Drozdzewski, G., Henscheid, S., Hoth, P., Juch, D., Littke, R., Vieth, A. and Wrede, V. (2009) The Pre-Permian of NW-Germany-Structure and Coalification Map [Das Präperm von NW-Deutschland-Struktur-und Inkohlungskarte]. Zeitschrift der Deutschen Gesellschaft für Geowissenschaften, 160, 159-172. https://doi.org/10.1127/1860-1804/2009/0160-0159

[9] Brink, H.-J. (2005) The Evolution of the North German Basin and the Metamorphism of the Lower Crust. International Journal of Earth Sciences, 94, 1103-1116. https://doi.org/10.1007/s00531-005-0037-7

[10] Brink, H.-J. (2005) Liegt ein wesentlicher Ursprung vieler großer Sedimentbecken in der thermischen Metamorphose ihrer Unterkruste? Zeitschrift der Deutschen Gesellschaft für Geowissenschaften, 156, 275-290. https://doi.org/10.1127/1860-1804/2005/0156-0275

[11] Brink, H.-J. (2002) Die Anomalien von Bramsche, wieder eine offene Frage? Erdöl Erdgas Kohle, 118, 18-22.

[12] Brink, H.-J. (2013) Die Intrusion von Bramsche-ein Irrtum im invertierten Niedersächsischen Becken? Zeitschrift der Deutschen Gesellschaft für Geowissenschaften, 164, 33-48. https://doi.org/10.1127/1860-1804/2013/0011

[13] Hoffmann, N., Hengesbach, L., Friedrichs, B. and Brink, H.-J. (2008) The Contribu- 
tion of Magnetotellurics to an Improved Understanding of the Geological Evolution of the North German Basin-Review and New Results. Zeitschrift der Deutschen Gesellschaft für Geowissenschaften, 4, 159. https://doi.org/10.1127/1860-1804/2008/0159-0591

[14] Dulce, J.-C. and Lewis, D.S. (2011) NW Germany-3D Interpretation of Intra-Carboniferous Reflections. OIL GAS European Magazine 4/2011, URBAN-VERLAG Hamburg/Wien GmbH.

[15] Brink, H.-J. (2011) The Crustal Structure around the Harz Mountains (Germany): Review and Analysis. Zeitschrift der Deutschen Gesellschaft für Geowissenschaften, 162, 235-250. https://doi.org/10.1127/1860-1804/2011/0162-0235

[16] Czerwonka, M. (2015) Tiefenseismische Untersuchung im Bereich des Harzes. Master Thesis, Institute of Geophysics, University Hamburg, Hamburg.

[17] Eckelmann, K., Nesbor, K.-D., Königshof, P., Linnemann, U., Hofmann, M., Lange, J.-M. and Sagawe, A. (2014) Plate Interactions of Laurussia and Gondwana during the Formation of Pangaea-Constraints from U-Pb LA-SF-ICP-MS Detrital Zircon Ages of Devonian and Early Carboniferous Siliciclastics of the Hörre Zone and Adjacent Areas (Rheno-Hercynian Zone, Central European Variscides). Gondwana Research, 25, 1484-1500. https://doi.org/10.1016/j.gr.2013.05.018

[18] Berthelsen, A. (1992) Mobile Europe. In: Blundell, D., Freeman, R. and Müller, S., Eds., A Continent Revealed: The European Geotraverse, Cambridge University Press, Cambridge, 11-32. https://doi.org/10.1017/CBO9780511608261.004

[19] Torsvik, T.H. and Trench, A. (1991) The Ordovician History of the Iapetus Ocean in Britain: New Palaeomagnetic Constraints. Journal of the Geological Society, 148, 423-425. https://doi.org/10.1144/gsigs.148.3.0423

[20] Trench, A. and Torsvik, T.H. (1991) A Revised Palaeozoic Apparent Polar Wandering Path for Southern Britain (Eastern Avalonia). Geophysical Journal International, 104, 227-233. https://doi.org/10.1111/j.1365-246X.1991.tb02506.x

[21] Torsvik, T.H., Smethurst, M.A., Briden, J.C. and Sturt, B.A. (1990) A Review of Palaeozoic Palaeomagnetic Data from Europe and Their Palaeogeographic Implications. In: McKerrow, W.S. and Scotese, C.R., Eds., Palaeozoic Palaeogeography and Biogeography, Geological Society (London) Memoir No. 12, 25-41. https://doi.org/10.1144/GSL.MEM.1990.012.01.02

[22] Torsvik, T.H., Olsesen, O., Ryan, P.D. and Trench, A. (1990) On the Palaeogeography of Baltica during the Palaeozoic: New Palaeomagnetic Data from the Scandinavian Caledonides. Geophysical Journal International, 103, 261-279. https://doi.org/10.1111/j.1365-246X.1990.tb01768.x

[23] Torsvik, T.H., Ryan, P.D., Trench, A. and Harper, D.A.T. (1991) Cambrian-Ordovician Paleogeography of Baltica. Geology, 19, 7-17.

https://doi.org/10.1130/0091-7613(1991)019<0007:COPOB >2.3.CO;2

[24] Torsvik, T.H., Smethurst, A., Van der Voo, P., Trench, A., Abrahamsen, N. and Halvorsen, E. (1992) Baltica. A Synopsis of Palaeomagnetic Data and Their Palaeo-Tectonic Implications: A Review of Palaeozoic Palaeomagnetic Data from Europe and Their Palaeogeographic Implications. Earth Science Reviews, 33, 133-152.

[25] Verniers, J., Pharaoh, T. andre, L., Debacker, T., de Vos, W., Everaerts, M., Herbosch, A., Samuelsen, J., Sintubin, M. and Vecoli, M. (2002) The Cambrian to Mid Devonian Basin Development and Deformation History of Eastern Avalonia, East of the Midlands Microcraton: New Data and a Review. In: Winchester, J.A., Pharaoh T.C. and Verniers, J., Eds., Palaeozoic Amalgamation of Central Europe, Geological Society, London, Special Publication 201, 47-93. 
https://doi.org/10.1144/GSL.SP.2002.201.01.04

[26] von Raumer, J.F. and Stampfli, G.M. (2008) The Birth of the Rheic Ocean-Early Palaeozoic Subsidence Patterns and Subsequent Tectonic Plate Scenarios. Tectonophysics, 461, 9-20. https://doi.org/10.1016/j.tecto.2008.04.012

[27] Zeh, A. and Gerdes, A. (2010) Baltica and Gondwana Derived Sediments in the Mid-German Crystalline Rise (Central Europe): Implications for the Closure of the Rheic Ocean. Gondwana Research, 17, 254-263. https://doi.org/10.1016/j.gr.2009.08.004

[28] Vozoff, K. (1987) The Magnetotelluric Method. In: Nabighian, M.N., Ed., Electromagnetic Methods in Applied Geophysics, Vol. 2, Application, Society of Exploration Geophysicists, Tulsa, 641-711.

[29] Jödicke, A. (1984) Zur Deutung magnetotellurisch nachgewiesener guter Leiter im tieferen Untergrund Nordwestdeutschlands. In: Haak, V. and Homilius, J., Eds., Protokoll über das 10. Kolloquium "Elektromagnetische Tiefenforschung" in Grafrath/Oberbayern, Hannover, Berlin, 331-334.

[30] Duba, A. (1977) Electrical Conductivity of Coal and Coal Char. Fuel, 56, 441-443. https://doi.org/10.1016/0016-2361(77)90074-6

[31] Duba, A., Huenges, E., Nover, G., Will, G. and Jödicke, H. (1988) Impedance of Black Shale from Münsterland 1 Bohrehole: An Anomalously Good Conductor? Geophysical Journal International, 94, 413-419. https://doi.org/10.1111/j.1365-246X.1988.tb02264.x

[32] Duba, A., Heikamp, S., Nover, G. and Will, G. (1993) The Unusual Effect of Pressure on the Electrical Conductivity of Rocks from the German Deep Drilling Program (KTB). Eos, Transactions of the American Geophysical Union, 74, 316.

[33] Jödicke, H. (1991) Zonen hoher elektrischer Krustenleitfähigkeit im Rhenoherzynikum und seinem nördlichen Vorland. Hochschulschriften, 24, $413 \mathrm{~S}$.

[34] Raab, S., Hoth, P., Huenges, E. and Müller, H.J. (1998) Role of Sulfur and Carbon in the Electrical Conductivity of the Middle Crust. JGR, 103, 9681-9689.

https://doi.org/10.1029/97JB03530

[35] Smith, J.T. and Booker, J.R. (1991) Rapid Inversion of Two- and Three-Dimensional Magnetotelluric Data. Journal of Geophysical Research, 96, 3905-3922. https://doi.org/10.1029/90JB02416

[36] Hoffmann, N., Jödicke, H. and Horejschi, L. (2005) Regional Distribution of the Lower Carboniferous Culm and Carboniferous Limestone Facies in the North German Basin. Derived from Magnetotelluric Soundings. Zeitschrift der Deutschen Gesellschaft für Geowissenschaften, 156, 323-339. https://doi.org/10.1127/1860-1804/2005/0156-0323

[37] Hengesbach, L. (2006) Magnetotellurische Studien im Nordwestdeutschen Becken: Ein Beitrag zur paläogeographischen Entwicklung des Unterkarbons. Dissertation Universität Münster.

[38] Kelch, H.J. and Paulus, B. (1980) Die Tiefbohrung Velpke-Asse Devon 1. Geol. Jb., A57, 3-175.

[39] Scheibe, R., Seidel, K., Vormbaum, M. and Hoffmann, N. (2005) Magnetic and Gravity Modelling of the Crystalline Basement in the North German Basin. Zeitschrift der Deutschen Gesellschaft für Geowissenschaften, 156, 291-298. https://doi.org/10.1127/1860-1804/2005/0156-0291

[40] Baldschuhn, R., Frisch, U. and Kockel, F. (1996) Geotektonischer Atlas von NWDeutschland 1: 300 000. BGR, Hannover. 
[41] Plein, E. (1995) Stratigraphie von Deutschland I-Norddeutsches Rotliegendbecken. Deutsche Stratigraphische Kommission (Hrsg.; Koordination und Redaktion: E. Plein für die Subkommission Perm-Trias) (1995). Cour. Forsch. Inst. Senckenberg, 183: 193 S.; 81 Abb., 10 Tab., 8 Taf.; Frankfurt a. M.

[42] Horejschi, L. (2002) Magnetotellurik und Erdmagnetische Tiefensondierung in der Ems-Region. Unpublished Dipl., Arb., Inst. f. Geophysik, Univ., Münster.

[43] Biehl, B.C., Reuning, L., Schoenherr, J., Lüders, V. and Kukla, P.A. (2016) Impacts of Hydrothermal Dolomitization and Thermochemical Sulfate Reduction on Secondary Porosity Creation in Deeply Buried Carbonates: A Case Study from the Lower Saxony Basin, Northwest Germany. AAPG Bulletin, 100, 597-621. https://doi.org/10.1306/01141615055

[44] Hoffmann, N., Jödicke, H. and Gerling, P. (2001) The Distribution of Pre-Westphalian Source Rocks in the North German Basin-Evidence from Magnetotelluric and Geochemical Data. Geologie en Mijnbouw, the Netherlands Journal of Geosciences, 80, 71-84. https://doi.org/10.1017/S0016774600022174

[45] Losecke, W., Knödel, K. and Müller, W. (1979) The Conductivity Distribution in the North German Sedimentary Basin Derived from Widely Spaced Areal Magnetotelluric Measurements. Geophysical Journal International, 58, 169-179. https://doi.org/10.1111/j.1365-246X.1979.tb01016.x

[46] Hoffmann, N., Jödicke, H., Fluche, B., Jording, A. and Müller, W. (1998) Modellvorstellungen zur Verbreitung potentieller präwestfalischer Erdgas-Muttergesteine in Norddeutschland-Ergebnisse neuer magnetotellurischer Messungen. Zeitschrift für Angewandte Geologie, 44, 140-158.

[47] Wiesker, B. (2003) Magnetotellurik entlang eines Südwest-Nordost-Profils durch das Zentrum des Norddeutschen Beckens. Dipl.-Arb., Inst. f. Geophys. Uni. Münster, $62 \mathrm{~S}$.

[48] Hermans, S. (1998) Ein-und zweidimensionale magnetotellurische Untersuchungen auf dem DEKORP-Profil 9601 zwischen Elbe und subherzynischem Becken. Unpublished Dipl.-Arb., 91 S., Inst. f. Geophys. Univ., Münster.

[49] Kreutzmann, A. (1998) Ein-und zweidimensionale magnetotellurische und inductionsmagnetische Untersuchungen entlang des DEKORP-Profils 9601 zwischen Harz und Flechtinger Höhenzug. Unpublished Dipl.-Arb., 107 Inst. f. Geophys. Univ., Münster.

[50] Besly, B.M. (1998) Carboniferous. In: Glennie, K.W., Ed., Petroleum Geology of the North Sea: Basic Concepts and Recent Advances, Blackwell, Oxford, 104-136. https://doi.org/10.1002/9781444313413.ch4

[51] Abbink, O.A., Devuyst, F.X., Grötsch, J., Hance, L., van Hoof, T.B., Kombrink, H. and van Ojik, K. (2009) The Lower Carboniferous of Key-Well UHM-02, Onshore the Netherlands, and Implications for Regional Basin Development. 71st EAGE Conference and Exhibition, Amsterdam, 8-11 June 2009. https://doi.org/10.3997/2214-4609.201400469

[52] Fleischer, U. (1954) Charakteristische erdmagnetische Baystörungen in Mitteleuropa und ihr innerer Anteil. Zeitschrift für Geophysik, 20, 120-136.

[53] Schmucker, U. (1959) Erdmagnetische Tiefensondierung in Deutschland 1957/59: Magnetogramme und erste Auswertung, Akad. Wiss. Göttingen, Math.-Phys. Kl., Beiträge Int. Geophys. Jahr, Heft 5.

[54] Untiedt, J. (1970) Conductivity Anomalies in Central and Southern Europe. Journal of Geomagnetism and Geoelectricity, 22, 131-149.

[55] Schäfer, A., Houpt, L., Brasse, H. and Hoffmann, N. (2011) The North German 
Conductivity Anomaly Revisited. Geophysical Journal International, 187, 85-98. https://doi.org/10.1111/j.1365-246X.2011.05145.x

[56] Neska, A. (2016) Conductivity Anomalies in Central Europe. Surveys in Geophysics, 37, 5-26. https://doi.org/10.1007/s10712-015-9349-8

[57] Gerling, P., Kockel, F. and Krull, P. (1999) Das Kohlenwasserstoff-Potential des Präwestfals im norddeutschen Becken-Eine Synthese. DGMK-Forschungsbericht, 433: 107 S., Hamburg.

[58] von Hartmann, H. (2003) Deformation of the Carboniferous on the Oldenburg High and the Location of the Variscan Front in Northwest Germany. Netherlands Journal of Geosciences/ Geologie en Mijnbouw, 82, 169-176. https://doi.org/10.1017/S0016774600020722

[59] Brink, H.-J., Burri, P., Lunde, A. and Winhard, H. (1992) Hydrocarbon Habitat and Potential of Swiss and German Molasse Basin: A Comparison. Eclogae Geologicae Helvetiae, 85, 715-732.

[60] Brink, H.-J. (2014) Signale der Milchstraße verborgen in der Sedimentfüllung des Zentraleuropäischen Beckensystems? Zeitschrift der Deutschen Gesellschaft für Geowissenschaften, 166, 9-20. https://doi.org/10.1127/1860-1804/2014/0081

[61] Brink, H.-J. (2015) Periodic Signals of the Milky Way Concealed in Terrestrial Sedimentary Basin Fills and in Planetary Magmatism? International Journal of Geosciences, 6, 831-845. https://doi.org/10.4236/ijg.2015.68067

[62] Brink, H.-J. (2019) Do Near-Solar-System Supernovae Enhance Volcanic Activities on Earth and Neighbouring Planets on Their Paths through the Spiral Arms of the Milky Way, and What Might Be the Consequences for Estimations of Earth's History and Predictions for Its Future? International Journal of Geosciences, 10, 563-575. https://doi.org/10.4236/ijg.2019.105032

[63] Brink, H.-J. (2010) Classification of the Central European Basin System (CEBS). DGMK Research Report 577-2/4.

[64] Klemme H.D. and Ulmishek, G.F. (1991) Effective Petroleum Source Rocks of the World: Stratigraphic Distribution and Controlling Depositional Factors. AAPG Bulletin, 75, 1809-1851. https://doi.org/10.1306/0C9B2A47-1710-11D7-8645000102C1865D

[65] Malzer, O., Rögl, F., Seifert, P., Wagner, L. Wessely, G. and Brix, F. (1993) Die Molassezone und deren Untergrund. In: Brix, F. and Schultz, O., Eds., Erdöl und Erdgas in Österreich, Naturhistorisches Museum Wien, Wien, 281-358.

[66] Gawlik, H.J., Frisch, W., Vecsei, A., Steiger, T. and Böhm, F. (1999) The Change from Rifting to Thrusting in the Northern Calcareous Alps as Recorded in Jurassic Sediments. Geologische Rundschau, 87, 644-657. https://doi.org/10.1007/s005310050237

[67] Frisch, W., Dunkl, I. and Kuhlemann, J. (2000) Post-Collisional Orogen-Parallel Large-Scale Extension in the Eastern Alps. Tectonophysics, 327, 239-265. https://doi.org/10.1016/S0040-1951(00)00204-3

[68] Linzer, H.-G., Decker, K., Persson, H., Dell'Mour, R. and Frisch, W. (2002) Balancing Lateral Orogenic Float of the Eastern Alps. Tectonophysics, 354, 211-237. https://doi.org/10.1016/S0040-1951(02)00337-2

[69] Ladwein, H.W. (1988) Organic Geochemistry of Vienna Basin: Model for Hydrocarbon Generation in Overthrust Belts. The American Association of Petroleum Geologists Bulletin, 72, 586-599. 
https://doi.org/10.1306/703C8ED4-1707-11D7-8645000102C1865D

[70] Royden, L.H. (1985) The Vienna Basin: A Thin-Skinned Pull-Apart Basin. The Society of Economic Paleontologists and Mineralogists.

https://doi.org/10.2110/pec.85.37.0319

[71] Hinsch, R., Decker, K. and Wagreich, M. (2005) 3-D Mapping of Segmented Active Faults in the Southern Vienna Basin. Quaternary Science Reviews, 24, 321-336. https://doi.org/10.1016/j.quascirev.2004.04.011

[72] Decker, K., Peresson, H. and Hinsch, R. (2005) Active Tectonics and Quaternary Basin Formation along the Vienna Basin Transform Fault. Quaternary Science Reviews, 24, 307-322. https://doi.org/10.1016/j.quascirev.2004.04.012

[73] Huchon, P., Le Pichon, X. and Rangin, C. (1994) Indochina Peninsula and the Collision of India and Eurasia. Geology, 22, 27-30. https://doi.org/10.1130/0091-7613(1994)022<0027:IPATCO >2.3.CO;2

[74] Linzer, H.-G. (1996) Kinematics of Retreating Subduction along the Carpathian Arc, Romania. Geology, 24, 167-170. https://doi.org/10.1130/0091-7613(1996)024<0167:KORSAT>2.3.CO;2

[75] Wessely, G. (1993) Der Untergrund des Wiener Beckens. In: Brix, F. and Schulz, O., Eds., Erdöl und Erdgas in Österreich, Beil, Wien, 249-280.

[76] Brockamp, B. (1967) Kurzbericht über die im Gebiet um Osnabrück durchgeführten seismischen Arbeiten des Instituts für Reine und Angewandte Geophysik der Universität Münster-Veröffentlichungen der Deutschen Geodätischen Kommission, Heft 153, Reihe B, 1-12.

[77] Teichmüller, M., Teichmüller, R. and Bartenstein, H. (1979) Inkohlung und Erdgas in Nordwestdeutschland. Eine Inkohlungskarte der Oberfläche des Oberkarbons. Fortschritte Geologie Rheinland und Westfalen, 27, 137-170.

[78] Teichmüller, M., Teichmüller, R. and Bartenstein, H. (1984) Inkohlung und Erdgas-eine neue Inkohlungskarte der Karbon-Oberfläche in Norddeutschland. Fortschritte Geologie Rheinland und Westfalen, 32, Seiten 11-34.

[79] Bachmann, G. and Grosse, S. (1989) Struktur und Entstehung des Norddeutschen Beckens-Geologische und geophysikalische Interpretation einer verbesserten Bouguer-Schwerekarte, Heft Nr. 2-Akademie für Geowissenschaften und Geotechnologien e.V., 47 S., 32 Abb., 1 Tab., 4 Taf., 3 Anl.; Hannover.

[80] Baldschuhn, R. and Kockel, F. (1999) Das Osning-Lineament am Südrand des Niedersachsen-Beckens. Zeitschrift der Deutschen Gesellschaft für Geowissenschaften, 150, 673-695. https://doi.org/10.1127/zdgg/150/2000/673

[81] Senglaub, Y., Littke, R. and Brix, M.R. (2005) Numerical Modelling of Burial and Temperature History as an Approach for an Alternative Interpretation of the Bramsche Anomaly, Lower Saxony Basin. International Journal of Earth Sciences, 90, 234-256. https://doi.org/10.1007/s00531-005-0033-y

[82] Senglaub, Y., Brix, M.R., Adriasola, A. and Littke, R. (2005) New Information on the Thermal History of the Southwestern Lower Saxony Basin, Northern Germany, Based on Fission Track Analysis. International Journal of Earth Sciences, 71, 747-772. https://doi.org/10.1007/s00531-005-0008-Z

[83] Senglaub, Y., Brix, M.R., Adriasola, A. and Littke, R. (2005) Neue Einblicke in die thermische Geschichte des südwestlichen Niedersächsischen Beckens. Erdöl Erdgas Kohle, 121, Heft 7/8.

[84] Rose, K.-H. and Gödecke, C.P. (1984) Mineral-Neubildungen des Osnabrücker Ber- 
glandes im Vergleich mit dem übrigen Nordwestdeutschland. In: Klassen, H., Ed., Geologie des Osnabrücker Berglandes, Naturwissenschaftliches Museum, Osnabrück, 567-643.

[85] Petrini, K. and Podladchikov, Yu. (2000) Lithospheric Pressure-Depth Relationship in Compressive Regions of Thickened Crust. Journal of Metamorphic Geology, 18, 67-77. https://doi.org/10.1046/j.1525-1314.2000.00240.x

[86] Bilgili, F., Götze, H.-J., Pasteka, R. and Schmidt, S. (2007) Intrusion versus Inversion-A 3D Density Model of the Southern Rim of the Northwest German Basin. International Journal of Earth Sciences, 98, 571-583. https://doi.org/10.1007/s00531-007-0267-y

[87] Stadler, G. and Teichmüller, R. (1971) Zusammenfassender Überblick über die Entwicklung des Bramscher Massivs und des Niedersächsischen Tektogens. In: Fortschritte in der Geologie von Rheinland und Westfalen, Band 18, Das höhere Oberkarbon von Westfalen und das Bramscher Massiv, Geologisches Landesamt NordrheinWestfalen, Krefeld, 547-564.

[88] Plaumann, S. (1983) Die Schwerekarte 1:500 000 der Bundesrepublik Deutschland (Bouguer-Anomalien), Blatt Nord. Geol. Jb., E 27, Seiten 3-16.

[89] Wonik, T. and Hahn, A. (1989) Karte der Magnetfeldanomalien Bundesrebublik Deutschland, Luxemburg, Schweiz und Österreich (westlicher Teil) 1:100 000. Geol. Jb., E 43, Seiten 3-21.

[90] Ziegler, P.A. and Dèzes, P. (2006) Crustal Evolution of Western and Central Europe. Article in Geological Society London Memoirs.

https://doi.org/10.1144/GSL.MEM.2006.032.01.03

[91] Bayer, U., Scheck, M., Rabbel, W., Krawczyk, C.M., Götze, H.-J., Stiller, M., Beilecke, T., Marotta, A.M., Barrio-Alvers, L. and Kuder, J. (1999) An Integrated Study of the NE German Basin. Tectonophysics, 314, 285-307. https://doi.org/10.1016/S0040-1951(99)00249-8

[92] Bormann, P., Bankwitz, P. and Schulze, A. (1989) Geophysikalische Ergebnisse und geologische Konsequenzen tiefenseismischer Messungen in der DDR. Freiberger Forschungshefte C, 440, 72-103.

[93] Mengel, K. and Kern, H. (1990) Petrologic versus Seismic Moho and Crustal Root Mysteries of the Hercynan Orogen. In: Freemann, R., Giese, P. and Mueller, St., Eds., The European Geotraverse: Integrative Studies, European Science Foundation, Strasbourg, 169-176.

[94] Mengel, K. and Kern, H. (1992) Evolution of the Petrological and Seismic MohoImplications for the Continental Crust-Mantle Boundary. Terra Nova, 4, 109-116. https://doi.org/10.1111/j.1365-3121.1992.tb00455.x

[95] Flick, H. (1986) The Hercynian Mountains-A Postorogenic Overthrusted Massif? Naturwissenschaften, 73, 670-671. https://doi.org/10.1007/BF00366689

[96] Kley, J., Franzke, H.-J., Jähne, F., Krawczyk, C., Lohr, T., Reicherter, K., ScheckWenderoth, M., Sippel, J., Tanner, D., van Gent, H. and the SPP Structural Geology Group (2008) Strain and Stress. In: Littke, R., Bayer, U., Gajewski, D. and Nelskamp, S., Eds., Dynamics of Complex Sedimentary Basins Dynamics of Complex Sedimentary Basins-The Example of the Central European Basin System, Springer-Verlag, Berlin/Heidelberg, 97-124, 519 S.

[97] Linnemann, U., Gehmlich, M., Heuse, T. and Schauer, M. (1999) Die Cadomiden und Varisziden im Thüringisch-Vogtländischen Schiefergebirge (Saxothuringisches Terrane). Beiträge zur Geologie von Thüringen, N.F., 6, 7-39. 
[98] Rappsilber, I. (2003) Struktur und Entwicklung des nördlichen Saale-Beckens (Sachsen-Anhalt): Geophysik und Geologie. Dissertation Martin-Luther-Universität HalleWittenberg, Halle (Saale). 